The research program of the Center for Economic Studies (CES) produces a wide range of theoretical and empirical economic analyses that serve to improve the statistical programs of the U.S. Bureau of the Census. Many of these analyses take the form of CES research papers. The papers are intended to make the results of CES research available to economists and other interested parties in order to encourage discussion and obtain suggestions for revision before publication. The papers are unofficial and have not undergone the review accorded official Census Bureau publications. The opinions and conclusions expressed in the papers are those of the authors and do not necessarily represent those of the U.S. Bureau of the Census. Republication in whole or part must be cleared with the authors.

\title{
THE EFFECTS OF OUTSOURCING ON THE ELASTICITY OF LABOR DEMAND
}

\author{
by
}

Mine Zeynep Senses *

The Johns Hopkins University

CES 06-07 March, 2006

All papers are screened to ensure that they do not disclose confidential information. Persons who wish to obtain a copy of the paper, submit comments about the paper, or obtain general information about the series should contact sang V. Nguyen, Editor, Discussion Papers, Center for Economic Studies, Washington Plaza II, Room 206, Bureau of the Census, Washington, DC 20233-6300, (301-763-1882) or INTERNET address snguyen@Ces.census.gov. 


\begin{abstract}
In this paper, I focus on the effects of outsourcing on conditional labor demand elasticities. I begin by developing a model of outsourcing that formalizes this relationship. I show that the increased possibility of outsourcing (modeled as a decline in foreign intermediate input prices and an increase in the elasticity of substitution between foreign and domestic intermediate inputs) should increase labor demand elasticities. I also show that, a decline in the share of unskilled labor, due either to skill biased technological change or to movement of unskilled labor intensive stages abroad, can work in the opposite direction and reverse the increasing trend in elasticities. I then test the predictions of the model using the U.S. Census Bureau's Longitudinal Research Database (LRD). The instrumental variable approach used in the estimation of labor demand equations is the main methodological contribution of this paper. I directly address the endogeneity of wages in the labor demand equation by using average nonmanufacturing wages for each location and year as an instrumental variable for the plant-level wages in the manufacturing sector.
\end{abstract}

The results support the main predictions of my model. U.S. manufacturing plants operating in industries that heavily outsource experienced an increase in their conditional labor demand elasticities during the 1980-1992 period. After 1992 elasticities began to decrease in outsourcing industries. This finding is consistent with the model which suggests that a decline in the share of unskilled labor in total cost could result in such a decrease in labor demand elasticities, precisely when the level of outsourcing is high. Estimates at the two-digit industry level provide further evidence in support of the hypothesis that heavily outsourcing industries experience greater increases in their elasticities.

* I thank, without implicating, Charlie Brown, John DiNardo, Juan Carlos Hallak, Chris Kurz, Sara LaLumia, and Jim Levinsohn, for very helpful comments. The research in this paper was conducted while the author was a Census Bureau research associate at the Michigan Census Research Data Center. Research results and conclusion expressed are those of the author and do not necessarily indicate concurrence by the Bureau of the Census. This paper has been screened to insure that no confidential data are revealed. Johns Hopkins University-SAIS; msenses1@jhu.edu. 


\section{Introduction}

During the past few decades, the U.S. economy has become much more integrated into the world economy through increased openness to international trade and as a source and host of capital flows. At the same time, many countries have abandoned policies that restrict foreign investment and have started offering better infrastructure and tax incentives aimed at encouraging foreign capital inflows. Together with improvements in technology that decreased transportation and monitoring costs significantly, this era is characterized by increased global production and vertical specialization of countries. However, during this period mobility of goods and capital has remained significantly higher than that of labor (Rodrik, 1997). Understanding the implications of these new aspects of globalization on labor markets is important and has policy implications concerning a large portion of the U.S. population and the rest of the world.

In this paper I contribute towards this understanding of globalization by investigating the effect of outsourcing on conditional (on output) labor demand elasticities. I begin by developing a theoretical model of outsourcing that formalizes this relationship and an empirical strategy that addresses the endogeneity of wages in the labor demand equation. I then use confidential plant-level data for the U.S. manufacturing sector to test for differential movements in labor demand elasticities over time in industries with different degrees of exposure to outsourcing, as suggested by the model.

Much of the previous research on labor market effects of international trade focuses on a single outcome, the increase in the skill premium observed in the U.S. and other 
developed nations. ${ }^{3}$ Most of these studies have focused on trade with developing countries as predicted by the Heckscher-Ohlin model and the Stolper-Samuelson theorem. Most have found that trade explains only a small portion of increased wage inequality. Krugman (1995) argues that this result is not surprising, given that trade with developing countries represents a very small portion of all trade. Although the debate still continues, many economists see skill biased technological change as the culprit, mainly because other explanations such as trade and the decline of unions fail to explain the extent of the observed wage gap.

Rodrik (1997) identifies labor demand elasticities as an equally important channel through which an increase in international trade can affect labor markets. He argues that greater product market competition, due to a decline in trade protection and the entry of less developed nations into the manufacturing sector, should make labor demand more elastic. The increased possibility of substituting foreign labor for domestic through outsourcing is also likely to flatten the labor demand curve. Rodrik (1997) emphasizes that outsourcing could impact labor markets even though its share is small in most industries. An increase in the threat of outsourcing could increase labor demand elasticities, even if actual levels of outsourcing do not change.

The current literature on the impact of international trade on labor demand elasticities has mainly focused on developing countries during trade liberalization periods. ${ }^{4}$ Slaughter (2001) is the first to test the relationship between openness and labor demand elasticities for a country that increasingly engages in outsourcing activity. He estimates labor demand elasticities for eight manufacturing sectors in the U.S. from 1961 through 1991, using

\footnotetext{
${ }^{3}$ Berman et al. (1994), Feenstra and Hanson (2001)

${ }^{4}$ Recent examples include Krishna et al.(1999), Fajnzylber and Maloney (2000a, 2000b) and Hasan et al. (2003).
} 
industry level data. His estimation results suggest that the demand for production labor has become more elastic in this period, but the contribution of openness is unclear.

Increased labor demand elasticities have important labor market consequences, and it is important to understand the significance of this channel. First, an increased labor demand elasticity alters the incidence of non-wage labor costs, such as payroll taxes or improved working conditions. Increased responsiveness of employers to wage changes increases workers' share of such costs. Second, higher elasticities result in greater instability in the labor market. If labor demand is more elastic, shocks to labor demand caused by changes in labor productivity will lead to higher volatility of employment and wages. Third, higher elasticities lead to a decline in the bargaining power of labor, weakening unions and decreasing labor's share of industry rents (Rodrik, 1997). The decline of unionism (Card, 2001) and the increase in within-group volatility in labor market conditions (Gottschalk and Moffitt, 1994) in recent decades are well documented in the U.S. These facts are consistent with the idea that labor demand elasticities have increased as the U.S. economy has become more integrated with the rest of the world (Rodrik, 1997).

In this paper, I develop a theoretical model of outsourcing that formalizes the relationship between outsourcing and conditional labor demand elasticities. I define outsourcing as trade in intermediate inputs. An increased possibility of outsourcing is modeled as a decline in foreign intermediate input prices, and an increase in the elasticity of substitution between foreign and domestic intermediate inputs. I show that both of these forces work to increase conditional labor demand elasticities. However, the model also suggests that this effect can be dominated by a decline in the share of unskilled labor which works in the opposite direction, precisely when the level of outsourcing is high. I test the 
validity of these predictions of the model using the U.S. Census Bureau's Longitudinal Research Database (LRD), which includes the Annual Survey of Manufacturers (ASM) and the Census of Manufacturers (CM).

The LRD provides detailed information on geographical location at the plant level, which is of crucial importance to the unique estimation strategy introduced in this paper. The existing literature on labor demand invariably relies on the questionable assumption that wages are exogenous at the industry or plant level for identification of the labor demand equation. Instead, I directly address the endogeneity of wages in the labor demand equation by using average non-manufacturing wages for each location and year as an instrumental variable for plant-level wages in the manufacturing sector. The source of identification is the variation in employment that results solely from differences in the alternative wage at the state level. Shocks to the non-manufacturing sector will change the alternative wage for workers in the manufacturing sector. This shifts the labor supply curve for manufacturing workers, identifying the manufacturing labor demand curve. ${ }^{5}$

In the empirical analysis, I identify differential movements of elasticities in heavily outsourcing industries compared to other industries facing a lower threat of outsourcing. Plant level data allow me to separate the changes in elasticities due to entry and exit of plants from the changes due to increased elasticity among continuing plants. I also estimate labor demand elasticities at the industry level and show that the threat of outsourcing is an important factor in explaining the trends in labor demand elasticities.

\footnotetext{
${ }^{5}$ This paper adds to the literature which identifies exogenous variation in wages in order to trace out the labor demand curve. For example, minimum wage studies use variation in minimum wage laws across states and time to identify employment effects (Brown, 1999). Similarly, Card (1990) uses the Mariel Boat Lift as an exogenous shift in less-skilled labor supply in Miami and examines its impact on wages and employment.
} 
The results support the main predictions of my model. U.S. manufacturing plants operating in industries that heavily outsource experienced an increase in their conditional labor demand elasticities during the 1980-1992 period. This increase in elasticities is more pronounced for continuing plants than for the unbalanced panel. After 1992, elasticities began to decrease in outsourcing industries. This finding is consistent with the model which suggests that a decline in the share of unskilled labor in total cost could result in such a decrease in labor demand elasticities precisely when the level of outsourcing is high. Estimates at the two-digit industry level provide further evidence in support of the hypothesis that heavily outsourcing industries experience greater increases in their elasticities.

In this paper I contribute to the literature on the effects of outsourcing on labor demand elasticities in three important ways. First, I develop the first model that formalizes the channels through which outsourcing could affect labor demand elasticities. While my model confirms that an increase in outsourcing should increase labor demand elasticities as stated by Rodrik (1997) and Slaughter (2001), it also suggests that the labor demand elasticities could decrease due to a decrease in the share of unskilled labor over time. I find that the empirical results for the U.S. support both of these predictions. My second contribution is with respect to the empirical strategy developed in this paper. I directly address the endogeneity problem in the labor demand equation using a unique instrumental variables approach. Use of plant-level data, the third contribution of this paper, is necessary for the implementation of this approach. In addition the use of plant-level instead of industrylevel data allows me to distinguish between within-plant changes in labor demand elasticities and changes due to plant entry and exit. Plant-level data also allow me to control for plantlevel heterogeneity and to estimate labor demand elasticities at the industry level. 
The paper is organized as follows. The next section presents the theoretical model of outsourcing and labor demand elasticities. Section 3 introduces the empirical specification. Section 4 discusses the empirical issues specific to the LRD. Section 5 reports the main results of the paper, regarding the differential movements of elasticities in industries with differing levels of exposure to outsourcing. Section 6 provides further evidence on the link between outsourcing and labor demand elasticities, at the 2-digit SIC level. Section 7 concludes.

\section{Model}

In this section I will introduce a model of foreign outsourcing and derive the conditional labor demand elasticity for skilled and unskilled labor. Foreign outsourcing is introduced into the model by incorporating trade in intermediate inputs within a given industry. The increased possibility of outsourcing over time is modeled as a decrease in foreign intermediate input prices and an increase in the elasticity of substitution between imported and domestically produced intermediate inputs.

Feenstra and Hanson (1996) suggest that being able to fragment production into selfcontained stages of differing skill intensity is a common feature of outsourcing industries. Facing a higher relative wage for unskilled labor at home, domestic firms in these industries move unskilled labor intensive production stages abroad. This practice is described in a U.S. International Trade Commission publication (1995) on the developments in productionsharing in the manufacturing sector. "Most major U.S. semiconductor manufacturers engage in production sharing to perform the labor-intensive stages of production in low wage regions. 
The industry conducts its most skilled and capital-intensive operations, IC (integrated circuits) design and fabrication, in the U.S. ... These wafers are then sent to affiliates in production-sharing countries for assembly and testing ... The assembled items are then reimported into the U.S under HTS provision 9802.” (p. 4-9). The model developed in this section captures this practice by incorporating the ability to fragment production stages and the disproportionate threat of outsourcing on unskilled labor in the U.S. manufacturing sector. Production of the single final good $\mathrm{Y}^{\mathrm{F}}$ involves two complementary production stages. These stages vary in terms of the type of labor used and the possibility of substitution between producing the input domestically and importing it from abroad. The first stage involves production of an intermediate input (I) that is produced using a domestic intermediate input (D) and an imported intermediate input $\left(\mathrm{y}_{1}\right)$. The imported intermediate input can be purchased from the world market at a price $\mathrm{p}_{1}$, whereas the domestic intermediate input is produced at home using capital (K) and unskilled labor (U) according to a Cobb-Douglas production function. The Intermediate input (I) is then produced combining the domestic intermediate input with its foreign counterpart according to the CES production function:

$I=\left[\beta D^{\rho}+(1-\beta) y_{1}{ }^{\rho}\right]^{1 / \rho}=\left[\beta\left(U^{\gamma} K^{1-\gamma}\right)^{\rho}+(1-\beta) y_{1}{ }^{\rho}\right]^{1 / \rho}$

The second stage of production involves research and development (R). It always takes place at home, using skilled labor and capital according to the following production function:

$R=S^{\alpha} K^{1-\alpha}$ 
Final output $\mathrm{Y}^{\mathrm{F}}$ is the finished product of these two stages with differing skill intensities ${ }^{6}$ :

$Y^{F}=\min \{R, I\}=\min \left\{S^{\alpha} K^{1-\alpha},\left[\beta\left(U^{\gamma} K^{1-\gamma}\right)^{\rho}+(1-\beta) y_{1}{ }^{\rho}\right]^{1 / \rho}\right\}$

Then, the minimum cost of producing the final good $\mathrm{Y}^{\mathrm{F}}$ is given by:

$C\left(w_{s}, w_{u}, p_{1}, r, Y^{F}\right)=\left\{\left(\frac{w_{s}}{\alpha}\right)^{\alpha}\left(\frac{r}{1-\alpha}\right)^{1-\alpha}+\left[\beta^{\sigma}\left(\left(\frac{w_{u}}{\gamma}\right)^{\gamma}\left(\frac{r}{1-\gamma}\right)^{1-\gamma}\right)^{1-\sigma}+\left(1-\beta^{\sigma}\right) p_{1}{ }^{1-\sigma}\right]^{1 / 1-\sigma}\right\} Y^{F}$

where $\sigma=1 / 1-\rho$ denotes the elasticity of substitution between foreign and domestic intermediate inputs. Wages for skilled and unskilled workers in this industry are $w_{s}$ and $w_{u}$, respectively. I assume the return to capital, r, and the price of the foreign intermediate input, $p_{1}$, are set at the world market.

\subsection{Demand for unskilled labor}

By Shepard's lemma, the conditional demand for unskilled labor (U) is found by differentiating the cost function with respect to $w_{u}$ :

$U\left(w_{u}, p_{1}, r, Y^{F}\right)=Y^{F} \beta^{\sigma}\left(\frac{w_{u}}{\gamma}\right)^{\gamma(1-\sigma)-1}\left(\frac{r}{1-\gamma}\right)^{(1-\gamma)(1-\sigma)}\left[\beta^{\sigma}\left(\left(\frac{w_{u}}{\gamma}\right)^{\gamma}\left(\frac{r}{1-\gamma}\right)^{1-\gamma}\right)^{1-\sigma}+(1-\beta)^{\sigma} p_{1}^{1-\sigma}\right]^{\sigma / 1-\sigma}$

The conditional labor demand elasticity (holding output constant) for unskilled labor can then be derived as:

\footnotetext{
${ }^{6}$ The production function specified here does not allow for substitution between skilled and unskilled intensive inputs. Plants combine a constant proportion of $\mathrm{R}$ and $\mathrm{I}$ in order to produce the final output. This functional form assumption is mainly to simplify the algebra and to isolate the effect of an increase in the possibility of outsourcing on unskilled labor. Allowing for substitution between R and I would not change the main results derived from the model, as long as the degree of substitution between domestic and foreign intermediate inputs is larger than the degree of substitution between $\mathrm{R}$ and $\mathrm{I}$.
} 
$\varepsilon_{u}=\frac{d U / U}{d w_{u} / w_{u}}=-\left[(1-\gamma)+\gamma \sigma s_{y_{1}, I}\right]$

Equation (2) represents the responsiveness of demand for unskilled labor to changes in wages along a production isoquant. $s_{y_{1}, I}$ is the share of foreign intermediate input $\left(\mathrm{y}_{1}\right)$ in the total cost of intermediate input production (I) and is equal to:

$s_{y_{1}, I}=\frac{p_{1} y_{1}}{C_{I} I}=\left[\left(\frac{\beta}{1-\beta}\right)^{\sigma}\left(\frac{C_{D}}{p_{1}}\right)^{1-\sigma}+1\right]^{-1}=\left[\left(\frac{\beta}{1-\beta} \frac{p_{1}}{C_{D}}\right)^{\sigma} \frac{C_{D}}{p_{1}}+1\right]^{-1}$

where $C_{D}$ is the unit cost of producing the intermediate input domestically and is:

$C_{D}=\left(\frac{w_{u}}{\gamma}\right)^{\gamma}\left(\frac{r}{1-\gamma}\right)^{1-\gamma}$

The intuition for Equation (2) is most easily represented graphically. Figure 1 illustrates the cost minimization problem of a competitive firm. Faced with $\mathrm{p}_{1}$ and $\mathrm{C}_{\mathrm{D}}$, the firm initially chooses to produce $I^{*}$ units of intermediate input using $D_{1}$ units of domestic intermediate input and $\mathrm{y}_{1}$ units of imported intermediate input (point A in Figure 1.1). The firm produces $\mathrm{D}_{1}$ units of domestic intermediate input using $\mathrm{K}_{1}$ units of capital and $\mathrm{U}_{1}$ units of unskilled labor, given $\mathrm{w}$ and $\mathrm{r}$ (point $\mathrm{B}$ in Figure 1.2). Assume now that the wage increases to w`. The total effect on the output constant labor demand elasticity has two components. First, holding output of $\mathrm{D}$ constant at $\mathrm{D}_{1}$, the steeper isocost line $N N$ implies substituting away from unskilled labor and towards capital in the production of domestic intermediate input (point $C$ in Figure 1.b). This effect is represented by the first term in Equation (2). This term alone would have represented the conditional labor demand elasticity, if the firm did not have the option of importing the intermediate input. However, an increase in the wage rate 
will now have a further effect on demand for labor through its effect on the unit cost of producing the domestic intermediate input $\left(\mathrm{C}_{\mathrm{D}}\right)$.

An increase in $C_{D}$ due to an increase in the wage will increase the relative cost of producing the intermediate input at home, flattening the isocost line in Figure $1.1(Q Q)$. The new cost minimizing equilibrium is at point $\mathrm{D}$, where the firm now chooses to substitute away from domestic production and towards importing the intermediate input. This decrease in domestic intermediate input production (reflected as a downward shift of the D isoquant) results in a decline in both domestic unskilled labor and capital usage (point E in Figure 1.2). The size of this decline in domestic input production, and hence in the demand for unskilled labor, is proportional to the share of unskilled labor in domestic input production. This effect is represented by the second term in Equation (2). ${ }^{7}$

\subsubsection{Decrease in the price of foreign intermediate input $\left(p_{1}\right)$}

It follows from Equation (2) that:

$$
\begin{aligned}
& \frac{\partial\left|\varepsilon_{u}\right|}{\partial p_{1}}=\sigma \gamma \frac{\partial s_{y_{1}, I}}{\partial p_{1}}<0 \text { if } \sigma>1 \\
& \text { where } \frac{\partial s_{y_{1}, I}}{\partial p_{1}}=\frac{1}{\left[\left(\frac{\beta}{1-\beta} \frac{p_{1}}{C_{D}}\right)^{\sigma} \frac{C_{D}}{p_{1}}+1\right]^{2}}\left(\left(\frac{\beta}{1-\beta}\right)^{\sigma} \frac{(1-\sigma)}{p_{1}}\left(\frac{C_{D}}{p_{1}}\right)^{1-\sigma}\right)
\end{aligned}
$$

\footnotetext{
${ }^{7}$ In this paper I only analyze conditional labor demand elasticities because: a) The increased possibility of outsourcing affects labor demand elasticities mainly through the substitution effect and b) Final good prices which are necessary to estimate total labor demand elasticities are not available at the plant level. However, it should be noted that increased product market competition faced by domestic firms (due to reduced trade protection in the U.S., the decline in transportation costs and entry of developing countries into the world trade market) will also make labor demand more elastic through the scale effect. Using plant-level data Levinsohn (1993) and Harrison (1994) find support for the idea that intensified trade competition curtails domestic market power. Neither of these studies focuses directly on labor demand elasticities, but the resulting increase in the elasticity of final good demand should make the derived labor demand curve even flatter over time.
} 
This implies that, if the elasticity of substitution between domestic and foreign intermediate inputs $(\sigma)$ is sufficiently large, the labor demand elasticity for unskilled labor increases as the price of foreign intermediate input decreases. A decrease in transportation costs and trade barriers along with policies encouraging foreign direct investment, and the provision of better infrastructure and tax incentives in developing countries have all decreased the cost of acquiring intermediate inputs from abroad. Feenstra and Hanson (2001) report that during the 1980s U.S. domestic prices rose faster than import prices. These within-industry price movements are consistent with U.S. firms finding imported inputs at increasingly lower prices, and replacing production stages they formerly performed at home with imports of intermediate inputs.

\subsubsection{Increase in the elasticity of substitution between foreign and domestic inputs ( $\sigma$ )}

The effect of increased substitutability between domestic and foreign inputs on the elasticity of demand for unskilled labor is:

$$
\begin{aligned}
& \frac{\partial\left|\varepsilon_{u}\right|}{\partial \sigma}=\gamma s_{y_{1}, I}+\sigma \gamma \frac{\partial s_{y_{1}, I}}{\partial \sigma} \\
& \text { where } \frac{\partial s_{y_{1}, I}}{\partial \sigma}=-\frac{1}{\left[\left(\frac{\beta}{1-\beta} \frac{p_{1}}{C_{D}}\right)^{\sigma} \frac{C_{D}}{p_{1}}+1\right]^{2}}\left(\frac{\beta}{1-\beta} \frac{p_{1}}{C_{D}}\right)^{\sigma} \ln \left(\frac{\beta}{1-\beta} \frac{p_{1}}{C_{D}}\right)
\end{aligned}
$$

The share of foreign intermediate input in the total cost of intermediate input production increases as the elasticity of substitution between foreign and domestic intermediate input increases, as long as $\frac{p_{1}}{1-\beta}<\frac{C_{D}}{\beta}$, i.e. the price of the foreign intermediate input is lower than the unit-cost of producing the input at home, adjusting for their respective weights in the 
production function. Arguably this condition does hold for the U.S. for inputs that are unskilled labor intensive, due to lower wages for unskilled workers abroad.

Developments in communication and information technologies allow enhanced monitoring and coordination of production activities in different locations. The increase in the rate of technological diffusion and the spread of knowledge contribute to higher levels of competence in intermediate input production in developing countries. Businesses that engage in outsourcing activities often cite the continuing rise in proficiency levels and productivity of Mexico's labor force and the ease with which producers can monitor the quality and efficiency of production in Mexico, along with cost-based advantages, as primary reasons for the ongoing increase in outsourcing to Mexico (U.S. International Trade Commission, 1995).

Rauch and Trindade (2003) provide the theoretical underpinnings for the anecdotal evidence on the role of improvements in information technology in increasing the elasticity of substitution between foreign and domestic inputs. They introduce a model based on matching frictions and investigate the impact of the increased ability of home firms to rule out more potential foreign trade partners in advance of attempting to form a match (improvement in "first cut" quality). They show that a decline in information barriers increases the probability that any international partnership will be successful and hence, increases the ability of producers to respond to price-based incentives. Their model suggests that this will result in a higher elasticity of substitution between national labor forces or the Armington elasticity of substitution between domestic and imported output.

Both the anecdotal and theoretical evidence imply that the foreign intermediate input is becoming a better substitute for domestic intermediate input. Together these results 
suggest that the demand for unskilled labor should become more elastic over time as foreign intermediate inputs have become better substitutes for their domestic counterparts.

\subsubsection{Decrease in share of unskilled labor in total cost $(\gamma)$}

So far, all the comparative statics discussed have focused on the increased possibility of outsourcing and have pointed to an increase in labor demand elasticities over time. However, conditional labor demand elasticity for unskilled workers also depends on the share of unskilled labor in the total cost of producing the domestic intermediate input $(\gamma)$. The effect of this share on the elasticity of demand for unskilled labor is:

$$
\frac{\partial\left|\varepsilon_{u}\right|}{\partial \gamma}=-1+\sigma s_{y_{1}, I}+\sigma \gamma \frac{\partial s_{y_{1}, I}}{\partial \gamma}=-1+\sigma s_{y_{1}, I}\left(1+\frac{\gamma}{s_{y_{1}, I}} \frac{\partial s_{y_{1}, I}}{\partial \gamma}\right)
$$

Then $^{8}$ if the share of the imported input in total intermediate input cost $\left(s_{y_{1}, I}\right)$ and the elasticity of substitution between foreign and domestic intermediate input $(\sigma)$ are sufficiently large (small), as $\gamma$ decreases, unskilled labor demand could become less (more) elastic $^{9}$. The first term in Equation (4) suggests that along the isoquant for the domestic input, the labor demand response to a wage change is smaller if labor's share is higher in domestic intermediate input production (the movement from B to C in Figure 1.2). The last term is reflective of the change in the relative cost of producing the domestic intermediate input compared to buying it from abroad. This term has the opposite sign as the first term and

${ }^{8}$ The term, $\frac{\gamma}{s_{y_{1}, I}} \frac{\partial s_{y_{1}, I}}{\partial \gamma}>0$ if $\frac{\partial\left(C_{D} / p_{1}\right)}{\partial \gamma}>0$ i.e. the higher is labor's share in the total input cost, the higher is the unit cost of domestic production $\left(\mathrm{C}_{\mathrm{D}}\right)$ relative to importing it at price $\mathrm{p}_{1}$. This condition is consistent with the fact that the most unskilled labor intensive production stages are the first to be outsourced.

$9 \frac{\partial\left|\varepsilon_{u}\right|}{\partial \gamma}>0$ if $s_{y_{1}, I} \sigma>\left(1+\frac{\gamma}{s_{y_{1}, I}} \frac{\partial s_{y_{1}, I}}{\partial \gamma}\right)^{-1}$ and $\frac{\partial\left|\varepsilon_{u}\right|}{\partial \gamma}<0$ otherwise. 
suggests that labor demand elasticity is higher when labor's share is higher. This is because a higher labor share will result in a larger increase in the unit cost of producing the domestic input, and hence a larger decrease in its production (the movement from A to D in Figure 1.1 and the inwards shift of the isoquant for domestic intermediate input in Figure 1.2). This channel is stronger if the imported intermediate input share and the elasticity of substitution between foreign and domestic intermediate inputs are higher.

As a proxy for $\gamma$, I calculate total wage payments to unskilled labor relative to total value of shipments in the manufacturing sector, for each year. As illustrated in Figure 2, this measure of $\gamma$ declines throughout the sample period. Both skill-biased technological change and increased specialization due to outsourcing, by shifting demand away from low-skilled activities, could explain this trend. Skill-biased technological change would result in a decline in unskilled labor's share as domestic firms substitute away from unskilled labor and towards skilled labor and capital. This will be reflected as a decline in the technology parameter $\gamma$ in the production function. Outsourcing would have a similar effect, if facing a relatively lower wage for unskilled labor abroad causes domestic firms to move production stages that use large amounts of unskilled labor abroad. This will result in increased specialization of U.S. plants in the production of skilled labor and capital intensive stages. In terms of the model, domestic intermediate input (D) production can be thought as a composite of many production stages at differing shares of unskilled labor in production. As plants outsource the production stages with high shares of unskilled labor, "average" $\gamma$ will decline.

The effect of $\gamma$ on labor demand elasticities depends on the share of imported intermediate input and the elasticity of substitution between foreign and domestic 
intermediate input $(\sigma)$. If $s_{y_{1}, I}$ and $\sigma$ are small, a decrease in $\gamma$ will result in a more elastic labor demand, working in the same direction as an increased possibility of outsourcing over time (modeled as a decrease in $p_{1}$ and an increase in $\sigma$ ). If the change in $\gamma$ is entirely due to the movement of unskilled labor intensive stages abroad, the $\gamma$-effect on labor demand elasticities can also be viewed as part of the outsourcing effect. Even if the decline in $\gamma$ is mostly due to skill-biased technological change, unless the speed or direction of this technological change is drastically different for outsourcing and non-outsourcing industries, there is no reason to think that this decline would result in differential movements in outsourcing and non-outsourcing industries. Thus if $s_{y_{1}, I}$ is small, even when $\gamma$ is decreasing, the model's prediction regarding the effect of outsourcing on labor demand elasticities is unchanged: Demand for unskilled labor in heavily outsourcing industries should become more elastic over time compared to that of non-outsourcing industries.

However, if $s_{y_{1}, I}$ and $\sigma$ are sufficiently large, then a decrease in $\gamma$ will work in the opposite direction of an increased possibility of outsourcing, reducing the labor demand elasticities. Hence, the labor demand elasticities could decrease or increase depending on which effect dominates the other. It is plausible that the $\gamma$-effect will become stronger later in the sample period, as the share of outsourcing and the elasticity of substitution between foreign and domestic intermediate inputs increases over time. Consequently, an increase in the importance of this effect will result in the underestimation or even the reversal of the effect of outsourcing on labor demand elasticities in industries with a high share of foreign intermediate input, especially later on in the sample period.

\subsection{Demand for skilled labor}


By Shepard's lemma, the conditional demand for skilled labor (S) is found by differentiating the cost function with respect to $w_{s}$ :

$S\left(w_{s}, r, Y^{F}\right)=Y^{F}\left(\frac{w_{s}}{\alpha}\right)^{\alpha-1}\left(\frac{r}{1-\alpha}\right)^{1-\alpha}$

The conditional elasticity of demand for skilled labor can then be derived as:

$\varepsilon_{S}=\frac{d S / S}{d w_{s} / w_{s}}=-(1-\alpha)$

An increase in the share of capital in the production of skilled labor intensive input (R) increases the labor demand elasticity for skilled labor. An increase in the possibility of outsourcing, due to a decline in the price of imported intermediate inputs and an increase in the elasticity of substitution between foreign and domestic intermediate input, has no effect on this elasticity. ${ }^{10}$

\section{Estimation of Labor Demand Elasticities: An Instrumental Variables Approach}

This section will focus on estimation of labor demand elasticities over time for each industry in the manufacturing sector. I discuss the biases associated with estimates that rely on the assumption that wages are exogenous at the industry or plant level for identification of the labor demand equation. I then propose an instrumental variables approach which eliminates the biases due to the endogeneity of wages in the labor demand equation.

\subsection{Why is OLS biased?}

\footnotetext{
${ }^{10}$ The elasticity of substitution between skilled labor and capital in the production of $\mathrm{R}\left(\sigma_{S K}\right.$ ) is equal to 1 . This is entirely due to the choice of functional form. More generally this elasticity would be equal to $-(1-\alpha) \sigma_{S K}$.
} 
The existing estimates of labor demand elasticities using plant or industry level data invariably rely on the assumption that wages are exogenous at the plant or industry level for identification. ${ }^{11}$ In these studies estimation of the conditional labor demand elasticities involves regressing total employment on wages, controlling for other factor prices and output. However, a closer look at the data reveals great variation in wages at the plant level, even among plants operating in the same industry, making the exogeneity assumption less viable. Possible sources of this observed variation are differences in worker quality among plants and the failure of the assumption that plants are price takers in the labor market. These alternative explanations will lead to biases in the OLS estimates that work in opposite directions.

Variation in the quality of workers hired has been proposed as an explanation for the observed variation in wages among plants. LRD does not include any variable that measures labor quality, such as education level or occupation of the labor force. As a result, the total number of employees will systematically underestimate the effective quantity of labor in plants with high quality labor. Similarly, since wages are calculated as a plant's expenditure on labor divided by its quantity of labor, wages will be systematically overestimated for plants with high-quality labor. Therefore, OLS will overestimate the own price response of plant level employment. Time-differencing will solve this problem only if quality differences among plants are time-invariant. If plants respond to changes in demand by altering their labor mix and therefore the quality of labor within the plant, even the time differenced equation will overestimate the (absolute value of) labor demand elasticities (Dunne and Roberts, 1993).

\footnotetext{
${ }^{11}$ See Hamermesh (1993) for an extensive survey of the literature.
} 
Although quality differences among workers might explain part of the observed wage dispersion, it cannot be the sole explanation. It is well documented that equally productive workers can receive different wages from different employers (Krueger and Summers, 1988). Burdett and Mortensen (1998) show that persistent wage differentials are consistent with strategic wage formation in an environment characterized by market frictions, even when workers are equally productive in all jobs. Such search models imply that in order to obtain a higher level of employment, the firm has to move along its upward sloping labor supply curve. Given the wage offered by other firms and the distribution of workers' reservation wages, firms that offer higher wages are more attractive to workers outside the firm. Similarly, fewer workers leave a given firm for another establishment higher up in the wage distribution. Hence, the higher the wage offer, the larger the steady state labor force available to the firm. ${ }^{12}$ Similarly, monopsony models ${ }^{13}$, starting from slightly different assumptions, reach essentially the same predictions regarding the supply curve facing the firm (Manning, 2003). Models based on search and monopsony both imply that wages are jointly determined by labor demand and an upward sloping labor supply, rather than a horizontal labor supply. As a result, shocks to labor demand will result in a change in wages, causing the independent variable to be correlated with the error term. This will lead to OLS estimates of labor demand elasticity (in absolute value) that are downward biased and inconsistent.

Hammermesh (1993) suggests that it is unlikely in reality that labor supply is perfectly horizontal for the units studied. Hence, estimating a system of labor demand and supply is more appropriate. He adds, "if a complete system cannot be specified, one may

\footnotetext{
${ }^{12}$ For an extensive survey of the literature on models of search in the labor market see Mortensen and Pissarides (1998).

${ }^{13}$ Manning (2003) emphasizes that the term monopsony in these models is not used to refer to a single buyer of labor, but simply to refer to the case that the supply of labor to an individual firm is not infinitely elastic. These models rely on two assumptions: there are frictions in the market and employers set wages.
} 
have sufficient variables that are not in the equation based on the cost or production function and that can be used to produce an instrument for the endogenous right hand side variable” (p. 450). Accordingly, in the next section, I introduce an instrumental variable approach to estimate the labor demand equation.

\subsection{Instrumental Variables approach}

In the empirical analysis that follows, instead of simply assuming that wages are exogenous at the plant level, I will identify the plant-level conditional labor demand elasticity for unskilled labor in the manufacturing sector using the variation in the plant's employment that results solely from differences in the non-manufacturing wages at its current location. The wage for a typical worker in the non-manufacturing sector will provide an alternative wage for workers employed in the manufacturing sector. Differences in this alternative wage, which is exogenous to the plant, will shift the labor supply curve of the workers in the manufacturing sector, identifying the elasticity of labor demand for an industry in the manufacturing sector.

The alternative wage varies across states over time, since the composition of the nonmanufacturing sector is not the same across states. For example, the introduction of a new technology in the agricultural sector will disproportionately affect the alternative wage in states where agriculture makes up a larger percentage of the non-manufacturing sector. This variation is independent of any quality upgrading at the plant-level and shocks to labor demand in the manufacturing sector. Hence, it affects the quantity of unskilled labor employed in the manufacturing sector only through its effect on labor supply faced by the plant. 
Estimation of $\varepsilon_{u}$ then requires using the non-manufacturing wage at each location as an instrumental variable for the plant level wages in the manufacturing industry. The second stage regression equation is:

$\ln U^{M}{ }_{i j t s}=\beta_{0 j t}+\beta_{1 j t} \ln \frac{w_{u, i j t s}^{\hat{M}}}{\overline{P_{j t}}}+\beta_{2 j t} \ln \frac{p_{1 i j t s}}{\overline{P_{j t}}}+\beta_{3 j t} \ln \frac{r_{i j t s}}{\overline{P_{j t}}}+\beta_{4 j t} \ln \frac{Y_{i j t s}^{F}}{\overline{P_{j t}}}+\beta_{i}+\varepsilon_{i j t s}$

The dependent variable in Equation (7) is the number of unskilled workers employed in plant $\mathrm{i}$ operating in industry $\mathrm{j}$ at time $\mathrm{t}$ in geographic location s. The coefficient $\beta_{1 j t}$ represents the conditional labor demand elasticity derived in Equation (2), reflecting the responsiveness of the demand for unskilled labor to changes in the wage rate. The variables $\mathrm{p}_{1}$ and $\mathrm{r}$ are the price of foreign intermediate input and the price of capital, respectively. $Y_{i j t s}^{F}$ is output and $\overline{P_{j t}}$ is a price index for industry $\mathrm{j}$ (4-digit SIC) at time t. $w_{u, j i j \mathrm{M}}^{\hat{M}}$ is the predicted wage for unskilled workers from the first stage regression:

$\ln \frac{w_{u, j i t s}^{M}}{\overline{P_{j t}}}=\theta_{0 j t}+\theta_{1 j t} \ln \frac{w_{u, t s}^{N M}}{\overline{P_{j t}}}+\theta_{2 j t} \ln \frac{p_{1 i j t s}}{\overline{P_{j t}}}+\theta_{3 j t} \ln \frac{r_{i j t s}}{\overline{P_{j t}}}+\theta_{4 j t} \ln \frac{Y_{i j t s}^{F}}{\overline{P_{j t}}}+\theta_{i}+u_{i j t s}$

where $w_{u, i j t s}^{M}$ is the wage rate for plant $\mathrm{i}$ in industry $\mathrm{j}$ at time $\mathrm{t}$ in geographic location $\mathrm{s}$ and $w_{u, t s}^{N M}$ is the average wage for production workers in the non-manufacturing sector in location s at time t. $\theta_{1 j \mathrm{t}}$ is positive since presumably there is some level of labor mobility between the non-manufacturing sector and this particular industry in the manufacturing sector. If alternative wages increase, the labor supply faced by the firm will decrease as some workers will move to the other sector. Consequently, the equilibrium manufacturing wage will increase. The plant level wages will not necessarily be equalized with the non-manufacturing 
wages at their location, i.e. $\theta_{1 j t} \neq 1$. This is because unskilled workers are not equally productive in the two sectors, due to industry-specific skills that are acquired on the job.

This approach relies on the validity of three assumptions. First, the manufacturing sector is small relative to total employment, so that a change in the manufacturing wage does not have a feedback effect on the non-manufacturing wages. ${ }^{14}$ Second, purchases from the non-manufacturing sector do not make up a big portion of the manufacturing sector's cost of production. This condition is needed to assure that a change in the non-manufacturing wage does not shift the manufacturing labor demand curve due to a change in the cost of production. Third, local labor demand shocks to the manufacturing sector are not correlated with shocks to the non-manufacturing sector. The validity of this assumption relies on the premise that the manufacturing market is national. Since the demand for the manufacturing goods is determined at the national level, labor demand shocks to the non-manufacturing sector in a given state will have no effect on the labor demand in the manufacturing sector in that state. Similarly, aggregate demand shocks that affect each state equally will not bias the instrumental variable estimates, which rely on cross-sectional variation at the state level.

\section{Estimation Issues}

I calculate three measures of alternative wage for a manufacturing sector worker in the non-manufacturing sector, using three different levels of geographic aggregation for each year. First, I compute average non-manufacturing wages for production workers in each state using the Current Population Survey (CPS). Second, for states with large enough samples in

\footnotetext{
${ }^{14}$ The share of manufacturing in total employment was approximately $20 \%$ in 1980 and has declined to $16 \%$ in 1995.
} 
the CPS, I calculate average non-manufacturing wages for plants that are located in MSAs and for plants that are not. Third, I use county-level non-manufacturing wages from the Covered Employment and Wages (CEW) dataset. ${ }^{15}$

Using an instrument at a lower level of geographic aggregation increases the variation in the instrument and provides more estimates that are statistically significant. But countylevel estimates have two main shortcomings. First, wages for production workers are not reported separately in the CEW dataset. Instead, I calculate alternative wages for total nonmanufacturing labor and use this wage as an instrument for production worker wages in the manufacturing sector. Second, the assumptions that the manufacturing sector is small relative to total employment and that the shocks to the manufacturing sector and the nonmanufacturing sector are uncorrelated, might be less valid for some counties. The failure of these assumptions will bias the estimates based on the county-level instrumental variables towards the OLS estimates. Therefore, in this paper, I will mostly rely on estimates based on state level instrumental variables, which do not suffer from this problem. I report results based on county-level instrumental variables mainly as robustness checks.

Unobserved heterogeneity at the plant level due to differences in organization, capital prices, the amount and quality of management inputs, vintage of capital equipment, extent of unionization, and quality of output produced can lead to permanent differences in plant employment and wages (Dunne, Roberts, 1993). Since many of these factors change slowly over time, they will be treated as time-invariant plant specific effects. Equations (7) and (8) will be estimated in three year differences for each industry and year in order to control for

\footnotetext{
15 The Covered Employment and Wages program is supervised by BLS's Office of Employment and Unemployment Statistics. CEW provides tabulations on the employment, total wages, and reporting units, of employees covered by various unemployment insurance programs.
} 
these unobserved time invariant plant fixed effects. ${ }^{16}$ Estimating the labor demand equation in differences also eliminates the variation in non-manufacturing wages at the state-level due to differences in schooling quality and skill composition of the labor force, which change slowly over time.

The prices of imported intermediate inputs and capital services are not reported at the plant level in the LRD. The prices of manufacturing sector inputs are set at the world market and changes in these prices are independent of changes in non-manufacturing wages at the state level. Similarly, the omission of the price of capital from the time differenced estimation equation will not bias the elasticity coefficients, if plants with certain time invariant characteristics (such as size and membership in a corporation) consistently face more favorable prices for capital.

The non-manufacturing wage at the state level is not a suitable instrument for the wages of skilled workers in the manufacturing sector. This is because skilled workers are much less mobile between sectors, due to their high degree of specialization and high level of job-specific human capital. Besides, given that outsourcing is mainly a threat for unskilledlabor-intensive production stages, the model introduced in the previous section suggests that outsourcing will not affect the elasticity of demand for skilled workers. Therefore, I will only estimate the labor demand elasticities for unskilled labor using the instrumental variable approach introduced in this paper.

The final estimation equation is then:

$\ln U^{M}{ }_{i j t s}=\beta_{1 j t} \ln \frac{w_{u, j i t s}^{\hat{M}}}{P_{j t}}+\beta_{4 j t} \ln \frac{Y_{i j t s}^{F}}{P_{j t}}+\beta_{i}+\varepsilon_{i j t s}$

\footnotetext{
${ }^{16}$ I will also estimate Equations (9) and (10) in five year differences in order to check for the robustness of the results.
} 
where, $w_{u, i j t s}^{\hat{M}}$ is the predicted wage for unskilled workers from the first stage regression: $\ln \frac{w_{u, i j t s}^{M}}{\overline{P_{j t}}}=\theta_{1 j t} \ln \frac{w_{u, t s}^{N M}}{\overline{P_{j t}}}+\theta_{4 j t} \ln \frac{Y_{i j t s}^{F}}{\overline{P_{j t}}}+\theta_{i}+u_{i j t s}$

\section{Empirical Results: Elasticity Estimates over Time}

I estimate conditional labor demand elasticities for production workers in the manufacturing sector for each year, using instrumental variables at three different levels of geographical aggregation. The coefficient of interest is $\beta_{1 j t}$ from Equation (9). I examine how this coefficient changes over time for industries with differing degrees of exposure to outsourcing. The model introduced in Section 3 suggests that labor demand in outsourcing industries should become more elastic over time as the possibility of outsourcing increases. However, this effect can be dominated by a decline in the share of unskilled labor, which works in the opposite direction precisely when the level of outsourcing is high.

Unless otherwise stated, in order to better reflect the underlying trends, the graphs presented in this section plot three year moving averages of the elasticity estimates, over time. All of the estimates summarized in the figures are significant at least at the $10 \%$ level and the instrument is valid with an F-statistic greater than $15 .{ }^{17}$ The standard errors are clustered at the level of geographic aggregation.

\subsection{All Manufacturing}

\footnotetext{
${ }^{17}$ Note that a downward (upward) sloping graph reflects an increase (decrease) in labor demand elasticities over time.
} 
In order to demonstrate the overall trends and to provide a benchmark, I estimate conditional labor demand elasticities for the whole manufacturing sector. In Figure 3, I plot these elasticities, estimated separately for the balanced and unbalanced panels, over time. The unbalanced panel includes all the plants that were surveyed in a given year and it is useful in understanding the overall trends in the sector. However, it fails to differentiate between changes in elasticities within a plant and changes in the composition of the underlying sample of plants due to entry and exit. The elasticities of plants that enter or exit the sample can consistently be different from those of the continuing plants.

In order to separately identify within-plant changes in elasticities, I estimate labor demand elasticities only for plants that were surveyed each year during the 1977-1995 period (the balanced panel). This sample includes plants that began operation prior to 1977, had not shut down by 1995 and were surveyed in each Annual Survey of Manufacturers in the 19771995 period. The balanced panel is not a random sample of plants and includes a higher proportion of large plants due to the ASM sampling strategy. ${ }^{18}$ In view of this, I also estimate elasticities separately for plants that were surveyed in all the Census of Manufacturers between 1977 and 1995 (the Census sample). Every plant under operation in the U.S. for that particular census year is surveyed in the Census of Manufacturers. This sample includes plants that began operation prior to 1977 , and had not shut down by 1995, as they enter the ASM sample. The Census sample is a more representative sample of the continuing plants, compared to the balanced panel. Table 1 reports the number of plants in the three-year differenced dataset for each sample and year.

\footnotetext{
${ }^{18}$ Approximately one third of the ASM panel is rotated in and out of the sample every five years in order to minimize the reporting burden on small plants. Only establishments with 250 employees or more and major producers in each of the product classes covered by the ASM are continued from sample to sample.
} 
The estimation results for plants surveyed each year (the balanced panel) and for plants surveyed in each Census of Manufacturers (the Census sample), along with the unbalanced panel of plants are illustrated in Figure 3. Elasticities for all three of the samples reported are estimated in three year differences, by pooling all manufacturing industries together. The elasticity estimates for the unbalanced panel vary between 0.2 and 0.7 in absolute value, showing a slight upward trend until 1987, when this trend reverses. The elasticities for the two sub-samples of continuing plants exhibit similar trends. For both samples labor demand becomes more elastic until 1991 and then becomes less elastic. Elasticities for the plants that were surveyed in every year between 1977 and 1995 are slightly lower than the sample of firms surveyed in each census and the unbalanced panel. ${ }^{19}$

I estimate labor demand elasticities for the unbalanced panel for the whole manufacturing sector using OLS along with instrumental variable estimates at three levels of geographic aggregation. The results based on three year differenced data are summarized in Figure 4. Compared to OLS, instrumental variable estimates reflect significantly higher labor demand elasticities for the majority of the period. This suggests that the bias due to the endogeneity of wages is more important than that due to unobserved quality differences. This is to be expected since including plant fixed effects, at least partially, solves the latter problem. The differences between alternative instrumental variables are statistically insignificant for most years. The estimates based on state- and MSA-level instrumental

\footnotetext{
${ }^{19}$ Over time the unbalanced panel estimates become statistically not different from the balanced panel estimates. From 1980 to 1995, the role of exit becomes smaller while entry becomes more important, in terms of the difference between the two samples. Compared to the unbalanced panel, in 1980, the plants that are not included in the balanced panel are those that would exit later on in the sample, whereas in 1995, the difference is due solely to those that are new entrants. This suggests that exiting plants are more elastic before exit, whereas no such difference is apparent for new entrants.
} 
variables are almost identical, and the estimates based on county-level instrumental variable are generally less elastic. ${ }^{20}$

\subsection{Heavy Outsourcers versus Other Industries}

Manufacturing-wide estimation, although providing a useful summary of the data, restricts elasticities to be the same for each industry, masking differences in trends across industries. The model introduced in this paper predicts that labor demand should become more elastic in industries in which there is an increasing threat of outsourcing. To see if the trends in elasticities are different in industries in which this threat has increased, I estimate elasticities separately for industries that outsource heavily and those that do not.

Outsourcing is concentrated in a small number of industries, reflecting the fact that the ease with which firms can substitute domestic labor with foreign inputs is not the same across industries. Although the share of imported intermediate inputs has been increasing considerably in the past two decades, the relative ranking of manufacturing industries in terms of their imported input share has been very stable over time (Campa and Goldberg, 1997). Feenstra and Hanson (1996) identify two characteristics of industries with high propensities to outsource: Production in these industries can be separated into self-contained stages and these production stages vary considerably in terms of skill intensity. The former makes it possible to move a production stage abroad, whereas the latter provides the incentive for doing so. These facts support the view that outsourcing industries are systematically different from other industries. They differ in terms of their production technology, which facilitates fragmentation of production among different countries.

\footnotetext{
${ }^{20}$ The finding that county level estimates are biased towards OLS is consistent with the failure of the assumptions (independence of labor demand shocks in manufacturing and non-manufacturing sectors, in particular) needed for the validity of the instruments, as discussed in the previous section.
} 
Therefore, I assume that an increase in the possibility of outsourcing is much more important in those industries that already engage in heavy outsourcing.

I identify heavily outsourcing 2-digit industries based on two measures of outsourcing commonly used in the literature. The first measure, developed by Feenstra and Hanson (1996), quantifies outsourcing as the share of imported intermediate inputs in total purchases of non-energy materials. ${ }^{21}$ The second measure identifies heavy outsourcers as the most frequent suppliers of the offshore assembly provision (OAP) known as 9802 in the current U.S. tariff code (Hanson, 1995 and U.S. International Trade Commission, 1995, 1999; and Swanson, 2004). ${ }^{22}$

Although the ranking of these industries differs between the two measures, both of these measures point to the same set of industries as heavy outsourcers. ${ }^{23}$ Industries that are heavy outsourcers according to both measures are: Textiles and Apparel (23), Leather and Leather Products (31), Non-Electrical Machinery (35), Electrical and Electronic Equipment (36), Transportation Equipment (37), Instruments and Related Products (38) and Miscellaneous Manufacturing Industries (39). I separately estimate elasticities for these industries that engage in heavy outsourcing and for industries that do not. Table 2 provides the full list of industries at the 2-digit SIC level, according to their outsourcing status.

\footnotetext{
${ }^{21}$ Feenstra and Hanson (1996) calculate this measure of outsourcing at the 4-digit SIC level. I aggregate their measure to the 2-digit SIC, weighting by industry value added.

${ }^{22}$ Under this provision, goods that are assembled abroad, using components manufactured in the U.S., receive preferential tariff treatment upon re-entry.

${ }^{23}$ Feenstra and Hanson (1996) identify footwear, electric and electronic machinery, instruments, and other industries, as the industries with the highest levels of outsourcing. Alternatively, the set of studies that use data from the OAP generally emphasize motor vehicles and motor vehicle parts, electrical and non-electrical machinery, and apparel, as the most frequent suppliers of the OAP program (Hanson, 1995, Swanson, 2004 and U.S International Trade Commission, 1995, 1999).
} 
Elasticity estimates over time for heavily outsourcing industries and other industries are reported in Figure 5.1 for the unbalanced panel. ${ }^{24}$ The estimates reported are based on state-level instrumental variables estimated in three-year differences. The results suggest that elasticities for outsourcing industries increase dramatically, from 0.2 in 1980 to 1.1 in 1987. The elasticities are relatively stable until 1992, when they start decreasing. During this period elasticities for other industries do not increase.

In industries characterized by high levels of outsourcing, failing to take into account changes in the composition of the underlying sample might result in underestimation of the importance of outsourcing on elasticities. For example, if a plant with high labor demand elasticity exits and moves its operations abroad, the labor demand elasticity estimates will be lower in the following year for the unbalanced panel. To illustrate this point, Figure 5.2.a plots the (three-year moving averages of the) elasticities for plants surveyed in every CM year between 1977 and 1995, for heavily outsourcing industries and for others. The results suggest that elasticities for continuing plants in outsourcing industries increase dramatically until 1992, when they start to decline. The difference in the trends between the unbalanced panel and the Census sample provides evidence for the hypothesis that the composition of the outsourcing industries is changing, as plants with higher labor demand elasticities leave. During this period, no consistent pattern emerges for the other industries, with elasticities varying in a narrow range.

Figure 5.2.b reports the 95\% confidence intervals around the elasticity estimates for outsourcing and non-outsourcing industries, for plants in the census sample. Before 1986, the elasticity estimates are not statistically different among industries with differing exposure to

\footnotetext{
${ }^{24}$ I check the robustness of the results to the choice of outsourcing industries, by eliminating one (and two) industry at a time from the heavily outsourcing industries. The results reported in this section are robust to these alternative classifications.
} 
outsourcing. Starting in 1986, the elasticity estimates are statistically different in every year, and labor demand is more elastic for heavily outsourcing industries compared to other industries.

In order to check whether the results are robust to the differencing used, I estimate elasticities using five-year differences for the Census sample. Time-differencing the data can exaggerate the measurement error by decreasing the amount of systematic variation in the explanatory variables. This bias will generally be lower for estimations based on specifications using long-differences (Griliches and Hausman, 1986). In the absence of such measurement error the estimates from three and five year differences should not be significantly different. Large differences between the two estimates signal misspecification of the estimation equation. Figure 5.2.c reports estimates from the three and five year differenced data. The main conclusion is unchanged. For outsourcing industries only, labor demand elasticities increase until 1992, then start decreasing.

I also check robustness of the results to the use of alternative instrumental variables at differing levels of geographical aggregation. I report the estimation results in Figure 5.2.d. As was the case for all manufacturing, elasticity estimates from specifications using stateand MSA-level instruments are almost the same. Estimates using county-level instrumental variable are slightly lower. For all three of the alternative instruments, the differences in the estimates for outsourcing and non-outsourcing industries are statistically significant. Again, the results are in line with the main predictions of the model.

\subsection{Discussion of the Results}


The results suggest that conditional labor demand elasticities for continuing plants increased in outsourcing industries from 1980 until 1992, when this trend reversed. During this period, no consistent patterns emerge for other industries that do not engage in heavy outsourcing. These findings are robust to alternative estimation strategies and sub-samples.

The model developed in this paper suggests that a technology change that induces substitution away from production workers in outsourcing industries could explain such a decrease in elasticities later in the sample period. I show in Section 2 that the share of foreign input in intermediate input production $\left(s_{y_{1}, I}\right)$ increases, as foreign and domestic inputs become better substitutes over time and as the price of foreign intermediate input decreases. Both of these effects work to increase the labor demand elasticities. However, the decline in the share of unskilled labor in domestic production $(\gamma)$ starts working in the opposite direction, decreasing the labor demand elasticities, precisely when the share of foreign intermediate input is high. The reversal of the increasing trend in labor demand elasticities could then be interpreted as this latter effect (the $\gamma$-effect) starting to dominate the effect of increased possibility of outsourcing (the outsourcing effect) on labor demand elasticities.

The model suggests that the increased threat of outsourcing and the decline in the share of unskilled labor could work in opposite directions. As discussed in Section 2 there are reasons to expect that the $\gamma$-effect would become stronger towards the end of the sample period, especially for heavy outsourcers. My results suggest that this effect starts dominating the outsourcing effect, leading to a decline in estimated elasticities, in 1992. The 1990-1991 
recession, which is characterized by major downsizing in the U.S. manufacturing sector, might have worked to speed this reversal in the upward trend in elasticities. ${ }^{25}$

\section{Empirical Results: Quantifying the Role of Outsourcing}

In this section I check the robustness of the main results reported in the previous section, by allowing labor demand elasticities and the degree of exposure to outsourcing to vary by industry and time. In a regression setting, I relate the trends in these elasticities to industry level explanatory variables associated with the increased possibility of outsourcing and the decline in share of unskilled labor in total cost of producing the domestic intermediate input.

In Table 3, I report average conditional labor demand elasticities estimated using state-level instrumental variables, for the unbalanced sample and the Census sample, by the 2-digit SIC level. The estimates suggest that there is some variation in elasticities across these industries. ${ }^{26}$ I also report the number of years for which these elasticities could be estimated significantly. For the unbalanced panel, I estimate 187 industry-year elasticities as significantly different from zero at least at $10 \%$ level (and with F-statistic $>15$ ), out of a total of 320 (16 years for 20 industries). The number of significant industry-year elasticity estimates is lower for the Census sample (172) as the sample size considerably decreases when I consider only the plants that did not enter or exit between 1977 and 1995. Despite the

\footnotetext{
${ }^{25}$ Unskilled labor is likely to bear the majority of the burden of downsizing due to skill biased technological change coupled with intensified foreign competition from less developed countries. Similarly, the 1990-1991 recession, by squeezing the profit margins at home, might have increased the incentives for replacing domestic labor with foreign intermediate inputs, intensifying the specialization of U.S. production in skilled labor and capital intensive production stages.

${ }^{26}$ When analyzing the summary statistics in Table 3, one must take into account that the years over which the average elasticities are calculated are not the same. The elasticity estimates that are not significant at least at the $10 \%$ level and those with an F-statistic less than 15 are not included when calculating the average.
} 
relatively few observations, I pursue this analysis, as it provides a broad comparison of my results with those of Slaughter (2001), who concludes that the link between increased openness and labor demand elasticities is a weak one and that any trend in elasticities is primarily explained by time controls.

The model developed in this paper suggests that the main variables explaining the trends in the elasticities would be the price of foreign intermediate inputs $\left(p_{1}\right)$, the elasticity of substitution between foreign and domestic intermediate inputs $(\sigma)$, and the share of production workers in total cost of producing the domestic intermediate input $(\gamma)$. As a proxy for $\gamma$, I compute wage payments to unskilled labor relative to total value of shipments in each industry and year, using the LRD. Since the price of foreign intermediate input and the elasticity of substitution between foreign and domestic intermediate inputs are not available, instead, I use several alternative measures that proxy for outsourcing. Table 4 provides the summary statistics for the industry level explanatory variables used in this section.

First, I use two alternative measures of foreign outsourcing developed in Feenstra and Hanson (1999). ${ }^{27}$ The "broad measure" of outsourcing is imported intermediate inputs relative to total expenditure on non-energy intermediates in each industry. The "narrow measure" is constructed by restricting the intermediate input purchases to those inputs purchased from the same 2-digit SIC industry as the good being produced. These measures are only available for 1987 and 1990 during the $1980-1995$ period. $^{28}$

\footnotetext{
${ }^{27}$ I thank Gordon Hanson for providing me with the broad and narrow measures of outsourcing constructed in Feenstra and Hanson (1999).

${ }^{28}$ Broad and narrow measures of outsourcing are available at the 4-digit SIC level. I aggregate them up to the 2-digit SIC level using industry value added as weights, since the elasticities are estimated at the 2-digit level.
} 
Feenstra and Hanson (1996) report that, in general, industries with high levels of final good imports also import high levels of intermediate inputs. They argue that this observation is consistent with the idea that outsourcing is a response to import competition. Accordingly, I use the ratio of imports to shipments for each industry as a proxy for outsourcing.

Outsourcing is mainly a threat for unskilled-labor-intensive production stages in the manufacturing sector. Thus, I use two other measures of import competition from low wage countries constructed by Schott (2002), as proxies for the threat of outsourcing. ${ }^{29}$ The first measure is the "value share" which reflects the share of an industry's import value that originates in low wage countries. The second measure, the "product share", is calculated as the fraction of products within an industry that originate in low wage countries. For both of these measures, countries are classified as low wage if they have less than $5 \%$ of the U.S. per capita GDP.

Finally, I use transportation costs as another measure capturing the increased possibility of substituting domestic labor with its foreign counterparts. Transportation costs for each industry and year are constructed by Feenstra (1996) and Schott (2002), as the ratio of c.i.f. (cost, insurance, and freight) import value to customs import value. A decline in transportation costs will increase outsourcing by decreasing the cost of intermediate inputs from the same industry, and should make labor demand more elastic according to the model.

In the regression analysis that follows, I estimate:

$$
\hat{\varepsilon}_{u, j t}^{\wedge}=\hat{\beta_{1, j t}}=\pi_{0}+\pi_{1} X_{j t}+\pi_{2} \gamma_{j t}+\sum_{j} \omega_{j} I D_{j}+\sum_{t} \theta_{t} T D_{t}+v_{j t}
$$

\footnotetext{
29 I thank Peter Schott for providing me with the product share and value share of imports from low wage
} countries, constructed in Schott (2002). 
where $\hat{\varepsilon_{u, j t}}$ s is the conditional labor demand elasticity for production workers estimated for industry $\mathrm{j}$ at time t for sample s. I estimate Equation (13) using elasticity estimates from two samples, the unbalanced sample and the Census sample. $X_{j t}$ is an industry level variable described above, that proxies for outsourcing. Since these alternative measures are highly correlated, I enter them one at a time to avoid multicollinearity. $\gamma_{j t}$ is the unskilled labor wage bill relative to the total value of shipments in industry $\mathrm{j}$ at time t. $I D_{j}$ are industry dummies that control for industry-specific, time-invariant level differences in elasticities. $T D_{j}$ are year dummies that control for time-specific level differences in elasticities, that are the same for each industry.

My model suggests that $\pi_{1}$ should be negative for alternative measures of outsourcing, indicating that an increase in the possibility of outsourcing will lead to more elastic labor demand estimates. Similarly, if a decline in transportation costs increases the ease with which plants can substitute between foreign and domestic intermediate inputs, its coefficient should be negative. According to the model, if $\pi_{2}$ is negative (positive), this will suggest that the $\gamma$-effect and the outsourcing effect are working in the opposite (same) direction. ${ }^{30}$ In this case, the decline in $\gamma$, keeping the level of outsourcing constant, will lead to less (more) elastic labor demand estimates. ${ }^{31}$

\footnotetext{
${ }^{30}$ This will be the case if $s_{y_{1}, I} \sigma\left(1+\frac{\gamma}{s_{y_{1}, I}} \frac{\partial s_{y_{1}, I}}{\partial \gamma}\right)>1$.

${ }^{31}$ The model introduced in Section 2 also implies that the $\gamma$-effect should become more important as the level of outsourcing increases, suggesting that $\gamma$ should enter the equation in a non-linear fashion. Accordingly, I also include the interaction of $\gamma$ with the outsourcing measure to test this hypothesis. This term is generally very imprecisely estimated and therefore is not reported. Given that the dependent variable
} 
Since the dependent variable is estimated, imprecision in estimating $\hat{\beta_{1, j t}}$ may generate heteroskedasticity. ${ }^{32}$ I correct for heteroskedasticity through weighted least squares as suggested by Anderson (1993). I first estimate Equation (13) using OLS. I use the squared residuals from this regression as the dependent variable in another OLS regression on the estimated variance of $\hat{\beta}_{1}$ and its square. I then construct the predicted values from this regression and use the inverse of these predicted values as weights for the weighted least squares estimation of Equation (13).

Table 5.A and 5.B report the estimated coefficients from Equation (13) where the dependent variable is the conditional labor demand elasticity for the unbalanced sample and the Census sample respectively. The unbalanced sample consists of all the plants that were surveyed in each ASM and CM year. The Census sample includes only the plants that were surveyed in all the Census of Manufacturers between 1977 and 1996. Elasticities are estimated using state-level instrumental variables in three year differences as described in Section 4.

The first column reports the estimated coefficients when each explanatory variable is entered without any other control variables. All the explanatory variables, except the narrow measure of outsourcing, are significant with the expected sign: An increase in outsourcing is associated with higher labor demand elasticities. Inclusion of $\gamma$ (proxied by the share of production workers in total value of shipments) does not change the sign of any of the outsourcing measures. This term always enters with a negative sign and is significant,

in Equation (13) is estimated, the number of observations is small, and that the (negative) correlation between $\gamma$ and $s_{y_{1}, I}$ is high, the lack of significance of the interaction variable is to be expected.

${ }^{32}$ The variance of the error term, $v_{j t}$, is equal to the variance of the error term in the true regression plus the variance of $\beta_{1, j t}$, unique to the industry-year combination. 
implying that as the share of unskilled labor in total cost declines, the labor demand curve becomes less elastic. This suggests that the outsourcing effect and the $\gamma$-effect work in opposite directions, the former leading to more elastic labor demand estimates. This finding is broadly consistent with the predictions of the model and the main results presented in the previous section.

The coefficients remain significant with no large changes in their magnitude when year dummies are included in the regression. The role of alternative measures of outsourcing (import competition, product share and value share) in explaining the labor demand elasticities is robust to the inclusion of industry dummies, alone and with year dummies. However, transportation costs and the share of unskilled labor cost in total value of shipments cease to be significant when industry dummies are added to the analysis.

The results reported in this section, for both the unbalanced panel and the Census sample, suggest that the increased possibility of outsourcing has contributed to the increase in labor demand elasticities. Unlike the results reported in Slaughter (2001), these findings are robust to the inclusion of year and industry controls. The results also provide some evidence in support of the hypothesis that a decline in the share of unskilled labor in total cost is working in the opposite direction of increased outsourcing.

\section{Conclusion}

In this paper, I have examined the effects of the increased possibility of outsourcing on conditional labor demand elasticities for unskilled labor. To achieve this, I developed a theoretical model that formalizes the link between outsourcing and labor demand elasticities. 
My model suggests that an increase in outsourcing should increase labor demand elasticities. However, this effect can be dominated by a decline in the share of unskilled labor, which works in the opposite direction precisely when the level of outsourcing is high. I then tested the main predictions of the model using confidential plant-level data for the U.S. manufacturing sector. The instrumental variable approach used in the estimation of labor demand equations is the main methodological contribution of this paper.

The results support the main predictions of my model. Until 1992, the demand for unskilled labor became more elastic in industries that heavily outsource. In 1992, this trend reversed, suggesting that the effect that operates through the decline in the share of unskilled labor began to dominate the outsourcing effect. No such trend is evident for industries that do not heavily engage in outsourcing. Unlike Slaughter (2001), I find that the elasticities increase only in outsourcing industries and that this trend could be attributed to the increased possibility of outsourcing over time. Industry level estimates provide further support for this hypothesis.

Further use of plant level data in understanding the implications of an increase in outsourcing on U.S. labor is likely to be fruitful. Plant-level data will allow identification of within-industry movements in relative employment and relative wages due to outsourcing, as well as the plant characteristics that affect the ease with which foreign labor can be substituted for domestic labor. Similarly, there is very little work which analyzes the impact of increased production-sharing in countries at the receiving end of outsourcing, for which the main predictions of the model are also applicable.

Outsourcing is increasingly becoming important in other sectors of the economy, especially services. It has begun to affect not only blue-collar workers but also white-collar 
workers. Although there is intensified political pressure to restrict outsourcing, this trend in the globalization of production is likely to continue and become increasingly more prevalent. It is of crucial importance to understand the full implications of the increased mobility of capital and goods in designing policies that will reduce the burden of these new aspects of globalization on workers.

\section{References}

Anderson, P.M., 1993. Linear Adjustment Costs and Seasonal Labor Demand: Evidence from Retail Trade Firms. Quarterly Journal of Economics 108(4), 1015-1042.

Bartelsman, E. J., Gray, W., 1996. The NBER Manufacturing Productivity Database. NBER Technical Working Paper \# 205, October 1996.

Berman, E., J. Bound, J., Griliches, Z., 1994. Changes in the Demand for Skilled Labor within U.S. Manufacturing: Evidence from the Annual Survey of Manufacturers. Quarterly Journal of Economics 109(2), 367-398.

Bernard, A., B., Jensen, J. B., 2002. The Deaths of Manufacturing Firms. Mimeo.

Bernard, A., Jensen, J. B. 2003. Falling Trade Costs, Heterogeneous Firms, and Industry Dynamics. NBER Working Paper \# 9639, April 2003.

Bernard, A., Jensen, J. B., Schott, P. K., 2002. Survival of the Best Fit: Exposure to Low Wage Countries and the (Uneven) Growth of U.S. Manufacturing Plants, August 2002.

Burdett, K., Mortensen, D. T., 1998. Wage Differentials, Employer Size, and Unemployment. International Economic Review 39(2), 257-273.

Brown, C., 1999. Minimum Wages, Employment, and the Distribution of Income. In: Ashenfelter, O., D. Card (Ed.), Handbook of Labor Economics, Volume 3. Elseiver Science Publishers BV, 2101-2163.

Campa, J., Goldberg, L. S., 1997. The Evolving External Orientation of Manufacturing: A Profile of Four Countries. FRBNY Economic Policy Review, 53-81. 
Card, D., 1990. The Impact of the Mariel Boatlift on the Miami Labor Market. Industrial \& Labor Relations Review 43(2), 245-257.

Card, D., 2001. The Effect of Unions on Wage Inequality in the U.S. Labor Market. Industrial \& Labor Relations Review 54(2), 296-315.

Dunne, T., Roberts M. J., 1993. The Long-run Demand for Labor: Estimates from Census Establishment Data. CES 93-13, September 1993.

Fajnzylber, P., Maloney, W.F., 2000. Labor Demand in Colombia, Chile and Mexico, Dynamic Panel Modeling. Mimeo, LAC PREM, June 16, 2000.

Fajnzylber, P., Maloney, W.F., 2000. Labor Demand and Trade Reform in Latin America. Mimeo, LAC PREM, June 2000.

Farber, H S. 1996. The Changing Face of Job Loss in the United States, 1981-1993. NBER Working Paper \# 5596, May 1996.

Feenstra, R.C., 1996. U.S. imports, 1972-1994: Data and Concordances. NBER Working Paper \# 5515, March 1996.

Feenstra, R.C., 1997. U.S. Exports: 1972-1994: With State Exports and Other U.S. Data,” NBER Working Paper \# 5990, 1997.

Feenstra, R.C., Hanson G.H., 1996. Globalization, Outsourcing and Wage Inequality. American Economic Review 86(2), 240-245.

Feenstra, R.C., Hanson G.H., 1999. The Impact of Outsourcing and High-Technology Capital on Wages: Estimates for the United States, 1979-1990. The Quarterly Journal of Economics 114, 907-940.

Feenstra, R.C., Hanson G.H., 2001. Global Production Sharing and Rising Inequality: A Survey of Trade and Wages. Handbook of International Economics, October 2001.

Feenstra, R.C., Romalis J., Schott P. K., 2002. U.S Imports, Exports and Tariff Data, 1989-2001. NBER Working Paper \# 9387, December 2002.

Gottschalk, P., Moffitt, R., 1994. The Growth of Earnings Instability in the U.S. Labor Market. Brookings Papers on Economic Activity, 217-272. 
Griliches, Z., J. A. Hausman, 1986. Errors in Variables in Panel Data. Journal of Econometrics 31(1), 93-118.

Hamermesh, D.S., 1986. The Demand for Labor in the Long-run. In: Ashenfelter, O., R. Layard (Ed.), Handbook of Labor Economics, Volume 1. Elseiver Science Publishers BV, pp. 429-471.

Hamermesh, D.S., 1993. Labor Demand. Princeton University Press, Princeton.

Hanson, G.H., 1995. The Effects of Offshore Assembly on Industry Location: Evidence from U.S Border Cities. NBER Working Paper \#5400, December 1995.

Hanson, G. H., 2001. The globalization of production. NBER Research Summary, Spring 2001.

Harrison, A. E., 1994. Productivity, Imperfect Competition and Trade Reform. Journal of International Economics 36, 53-73.

Hasan R., Mitra D., Ramaswamy K.V., 2003. Trade Reforms, Labor Regulations and Labor Demand Elasticities: Empirical Evidence from India. NBER Working Paper \#9879, 2003.

Helpman, E., Krugman, P., 1989. Trade Policy and Market Structure. MIT Press.

Krishna P, Devashish, M., Chinoy, S., 2001. Trade Liberalization and Labor Demand Elasticities: Evidence from Turkey. Journal of International Economics 55(2), 391-409.

Krueger, A. B., Summers, L. H., 1988. Efficiency Wages and the Inter-Industry Wage Structure. Econometrica 56(2), 259-293.

Krugman, P., 1995. Technology, Trade and Factor Prices. NBER Working Paper \#5355, 1995.

Levinsohn, J. 1993. Testing the Imports-as-Market-Discipline Hypothesis. Journal of International Economics 35, 1-22.

Mortensen, D. T., Pissarides, C. A., 1999. New Developments in Models of Search in the Labor Market. In: Ashenfelter, O., D. Card (Ed.), Handbook of Labor Economics, Volume 3B. North-Holland, Amsterdam, pp. 2567-2627. 
Manning, A., 2003. Monopsony in Motion: Imperfect Competition in Labor Markets. Princeton University Press, Princeton N.J.

National Bureau of Economic Research, 1997. Manufacturing Productivity Database. Available on-line at www.nber.org.

Rauch, J. E., Trindade, V., 2003. Information, International Substitutability, and Globalization. The American Economic Review 93(3), 775-791.

Revenga, A. L., 1992. Exporting Jobs? The Effect of Import Competition on Employment and wages in U.S. manufacturing. Quarterly Journal of Economics, 255-284.

Rodrik, D., 1997. Has Globalization Gone Too Far? Institute for International Economics, Washington DC.

Schott, P. K., 2002. Moving Up and Moving Out: U.S. Product-Level Exports and Competition from Low Wage Countries. Yale School of Management mimeo.

Slaughter, M., 2001. International Trade and Labor-Demand Elasticities. Journal of International Economics 54, 27-56.

Swenson, D. L., 2004. Overseas Assembly and Country Sourcing Choices. NBER Working Paper \#10697, 2004.

U.S. International Trade Commission, 1994. Production Sharing: Use of U.S. Components and Materials in Foreign Assembly Operations, 1990-1993. Publication 2886, December 1994.

U.S. International Trade Commission, 1999. Production Sharing: Use of U.S. Components and Materials in Foreign Assembly Operations, 1995-1998. Publication 3265, December 1999. 
Table 1 Number of Plants in Alternative Samples by Year

\begin{tabular}{|c|c|c|c|}
\hline Year & Unbalanced & Census & Balanced \\
\hline 1980 & 26314 & 16350 & 9905 \\
1981 & 23124 & 14479 & 9905 \\
1982 & 36255 & 22191 & 9905 \\
1983 & 34660 & 22492 & 9905 \\
1984 & 18216 & 12813 & 9905 \\
1985 & 22383 & 15679 & 9905 \\
1986 & 19832 & 14467 & 9905 \\
1987 & 34575 & 24041 & 9905 \\
1988 & 33212 & 23426 & 9905 \\
1989 & 20462 & 15494 & 9905 \\
1990 & 24367 & 18306 & 9905 \\
1991 & 24420 & 18736 & 9905 \\
1992 & 36594 & 25260 & 9905 \\
1993 & 38307 & 24421 & 9905 \\
1994 & 21599 & 14928 & 9905 \\
1995 & 24547 & 15990 & 9905 \\
\hline
\end{tabular}

The unbalanced sample includes all the plants that were surveyed in a given year. The Census sample includes plants that were surveyed in all the Census of Manufacturers between 1977 and 1995 (1977, 1982, 1987, 1992). The balanced sample includes plants that were surveyed each year during the 1977-1995 period.

\section{Table 2 Industries According to Outsourcing Status}

\begin{tabular}{|l|l|l|l|}
\hline SIC & Heavy Outsourcers & SIC & Others \\
\hline 23 & Apparel and other textile products & 20 & Food and kindred products \\
31 & Leather and leather products & 21 & Tobacco manufactures \\
35 & Industrial machinery and equipment & 22 & Textile mill products \\
36 & Electrical and electronic equipment & 24 & Lumber and wood products \\
37 & Transportation equipment & 25 & Furniture and fixtures \\
38 & Instruments and related products & 26 & Paper and allied products \\
39 & Miscellaneous manufacturing & 27 & Printing and publishing \\
& industries & 28 & Chemicals and allied products \\
& & 29 & Petroleum and coal products \\
& & 30 & Rubber and miscellaneous plastics \\
& & 32 & products \\
& & 33 & Stone, clay, glass, and concrete \\
& & 34 & Products \\
& & & \\
\hline
\end{tabular}


Table 3 Conditional Labor Demand Elasticity Estimates: Summary Statistics

\begin{tabular}{|c|cc|cc|}
\hline SIC2 & \multicolumn{3}{|c|}{ Unbalanced Sample } & \multicolumn{2}{c|}{ Census Sample } \\
& Mean & Number & Mean & Number \\
\hline 20 & -0.43 & 8 & -0.32 & 9 \\
21 & -1.04 & 3 & -1.36 & 3 \\
22 & -0.69 & 12 & -0.91 & 10 \\
23 & -1.22 & 14 & -1.5 & 10 \\
24 & -0.8 & 9 & -0.67 & 8 \\
25 & -1.37 & 6 & -1.57 & 5 \\
26 & -0.34 & 7 & -0.33 & 7 \\
27 & -0.57 & 8 & -0.62 & 8 \\
28 & -0.54 & 8 & -0.38 & 11 \\
29 & -0.35 & 9 & -0.35 & 9 \\
30 & -0.6 & 6 & -0.6 & 6 \\
31 & -1.82 & 8 & -1.27 & 5 \\
32 & -0.82 & 8 & -0.88 & 8 \\
33 & -0.56 & 12 & -0.54 & 12 \\
34 & -1 & 12 & -0.95 & 12 \\
35 & -0.71 & 16 & -0.77 & 14 \\
36 & -0.75 & 16 & -0.67 & 14 \\
37 & -1.05 & 6 & -1.06 & 5 \\
38 & -0.83 & 11 & -0.75 & 9 \\
39 & -0.97 & 8 & -0.96 & 7 \\
\hline All & -0.71 & 187 & -0.43 & 312 \\
\hline
\end{tabular}

Conditional labor demand elasticities for production workers estimated using state-level instrumental variable in three year differences. The unbalanced sample includes all the plants that were surveyed in a given year. The Census sample includes plants that were surveyed in all the Census of Manufacturers between 1977 and 1995 $(1977,1982,1987,1992)$

Table 4 Summary Statistics for Explanatory Variables

\begin{tabular}{|l|l|l|}
\hline & Mean & $\begin{array}{l}\text { Standard } \\
\text { Deviation }\end{array}$ \\
\hline Low Wage Country Competition & & \\
$\quad$ Product Share & 0.54 & 0.19 \\
$\quad$ Value Share & 0.07 & 0.08 \\
Share of Imports & 0.37 & 0.37 \\
Outsourcing & & \\
$\quad$ Broad & 0.12 & 0.06 \\
Narrow & 0.05 & 0.05 \\
Freight & 0.06 & 0.02 \\
Share of Production Workers in Total & & \\
Value of Shipments & 0.11 & 0.04 \\
\hline
\end{tabular}


Table 5.A Quantifying the Role of Outsourcing: The Unbalanced Panel

\begin{tabular}{|c|c|c|c|c|c|c|c|}
\hline & \multicolumn{2}{|c|}{ No Controls } & \multicolumn{2}{|c|}{ Year Dummies } & $\begin{array}{l}\text { Industry } \\
\text { Dummies }\end{array}$ & $\begin{array}{l}\text { Industry \& Year } \\
\text { Dummies }\end{array}$ & Observations \\
\hline Value Share & $\begin{array}{l}-0.969 * * \\
(0.411)\end{array}$ & $\begin{array}{l}-0.673 * * * \\
(0.158)\end{array}$ & $\begin{array}{l}-1.29 * * * \\
(0.4)\end{array}$ & $\begin{array}{l}-0.622 * * * \\
(0.163)\end{array}$ & $\begin{array}{l}-1.833^{* *} \\
(0.891)\end{array}$ & $\begin{array}{l}-2.18 * * \\
(1.058)\end{array}$ & 187 \\
\hline $\begin{array}{l}\text { Share of Production Workers in } \\
\text { Total Value of Shipments }\end{array}$ & & $\begin{array}{l}-2.720 * * * \\
(0.158)\end{array}$ & & $\begin{array}{l}-2.683 * * * \\
(0.708)\end{array}$ & & & \\
\hline Product Share & $\begin{array}{l}-0.838 * * * \\
(0.159)\end{array}$ & $\begin{array}{l}-0.806^{* *} \\
(0.389)\end{array}$ & $\begin{array}{l}-0.805^{* * *} \\
(0.160)\end{array}$ & $\begin{array}{l}-1.107 * * * \\
(0.380)\end{array}$ & $\begin{array}{l}-1.15^{* * *} \\
(0.341)\end{array}$ & $\begin{array}{l}-0.8 * \\
(0.455)\end{array}$ & 187 \\
\hline $\begin{array}{l}\text { Share of Production Workers in } \\
\text { Total Value of Shipments }\end{array}$ & & $\begin{array}{l}-3.271 * * * \\
(0.67)\end{array}$ & & $\begin{array}{l}-3.124 * * * \\
(0.656)\end{array}$ & & & \\
\hline Share of Imports & $\begin{array}{l}-0.232^{* * *} \\
(0.09)\end{array}$ & $\begin{array}{l}-0.268 * * * \\
(0.085)\end{array}$ & $\begin{array}{l}-0.265 * * * \\
(0.889)\end{array}$ & $\begin{array}{l}-0.283 * * * \\
(0.084)\end{array}$ & $\begin{array}{l}-0.429 * * \\
(0.179)\end{array}$ & $\begin{array}{l}-0.554 * * * \\
(0.186)\end{array}$ & 187 \\
\hline $\begin{array}{l}\text { Share of Production Workers in } \\
\text { Total Value of Shipments }\end{array}$ & & $\begin{array}{l}-3.712 * * * \\
(0.701)\end{array}$ & & $\begin{array}{l}-3.640 * * * \\
(0.701)\end{array}$ & & & \\
\hline Outsourcing & & & & & & & \\
\hline Narrow Measure & $\begin{array}{l}-2.79 * * \\
(1.223)\end{array}$ & $\begin{array}{l}-2.402 * \\
(1.232)\end{array}$ & $\begin{array}{l}-3.873 * * * \\
(1.332)\end{array}$ & $\begin{array}{l}-3.370 * * \\
(1.406)\end{array}$ & & & 24 \\
\hline $\begin{array}{l}\text { Share of Production Workers in } \\
\text { Total Value of Shipments }\end{array}$ & & $\begin{array}{l}-3.326 * \\
(1.972)\end{array}$ & & $\begin{array}{l}-3.050 \\
(2.009)\end{array}$ & & & \\
\hline Broad Measure & $\begin{array}{l}-0.956 \\
(1.683)\end{array}$ & $\begin{array}{l}-1.92 \\
(1.547)\end{array}$ & $\begin{array}{l}-1.132 \\
(1.765)\end{array}$ & $\begin{array}{l}-2.125 \\
(1.615)\end{array}$ & & & 24 \\
\hline $\begin{array}{l}\text { Share of Production Workers in } \\
\text { Total Value of Shipments }\end{array}$ & & $\begin{array}{l}-4.831^{* *} \\
(2.136)\end{array}$ & & $\begin{array}{l}-4.932 * * \\
(0.214)\end{array}$ & & & \\
\hline $\begin{array}{l}\text { Transportation Costs } \\
\text { Share of Production Workers in } \\
\text { Total Value of Shipments }\end{array}$ & $\begin{array}{l}2.172 * \\
(1.193)\end{array}$ & $\begin{array}{l}2.231 * * \\
(1.127) \\
-3.409 * * * \\
(0.663)\end{array}$ & $\begin{array}{l}2.025^{*} \\
(1.191)\end{array}$ & $\begin{array}{l}1.922^{*} \\
(1.147) \\
-3.438 * * * \\
(0.668)\end{array}$ & $\begin{array}{l}4.350 \\
(2.986)\end{array}$ & $\begin{array}{l}3.684 \\
(2.931)\end{array}$ & 187 \\
\hline
\end{tabular}


Table 5.B Quantifying the Roles of Outsourcing: The Census Sample

\begin{tabular}{|c|c|c|c|c|c|c|c|}
\hline & \multicolumn{2}{|c|}{ No Controls } & \multicolumn{2}{|c|}{ Year Dummies } & $\begin{array}{l}\text { Industry } \\
\text { Dummies }\end{array}$ & $\begin{array}{l}\text { Industry \& Year } \\
\text { Dummies }\end{array}$ & Observations \\
\hline Value Share & $\begin{array}{l}-1.012 * * * \\
(0.411)\end{array}$ & $\begin{array}{l}-0.826 * * \\
(0.391)\end{array}$ & $\begin{array}{l}-1.165 * * * \\
(0.417)\end{array}$ & $\begin{array}{l}-0.785^{* *} \\
(0.39)\end{array}$ & $\begin{array}{l}-2.168 * * * \\
(0.808)\end{array}$ & $\begin{array}{l}-1.739 * \\
(0.930)\end{array}$ & 172 \\
\hline $\begin{array}{l}\text { Share of Production Workers in } \\
\text { Total Value of Shipments }\end{array}$ & & $\begin{array}{l}-2.888 * * * \\
(0.613)\end{array}$ & & $\begin{array}{l}-3.112 * * * \\
(0.613)\end{array}$ & & & \\
\hline Product Share & $\begin{array}{l}-0.652 * * * \\
(0.142)\end{array}$ & $\begin{array}{l}-0.525 * * * \\
(0.137)\end{array}$ & $\begin{array}{l}-0.609 * * * \\
(0.154)\end{array}$ & $\begin{array}{l}-0.394 * * * \\
(0.151)\end{array}$ & $\begin{array}{l}-0.952 * * * \\
(0.251)\end{array}$ & $\begin{array}{l}-0.732 * * \\
(0.384)\end{array}$ & 172 \\
\hline $\begin{array}{l}\text { Share of Production Workers in } \\
\text { Total Value of Shipments }\end{array}$ & & $\begin{array}{l}-2.328 * * * \\
(0.553)\end{array}$ & & $\begin{array}{l}-2.608 * * * \\
(0.618)\end{array}$ & & & \\
\hline Share of Imports & $\begin{array}{l}-0.159 * * \\
(0.08)\end{array}$ & $\begin{array}{l}-0.162 * * \\
(0.074)\end{array}$ & $\begin{array}{l}-0.140^{*} \\
(0.081)\end{array}$ & $\begin{array}{l}-0.122 * \\
(0.073)\end{array}$ & $\begin{array}{l}-0.218 \\
(0.150)\end{array}$ & $\begin{array}{l}-0.132 \\
(0.166)\end{array}$ & 172 \\
\hline $\begin{array}{l}\text { Share of Production Workers in } \\
\text { Total Value of Shipments }\end{array}$ & & $\begin{array}{l}-2.772 * * * \\
(0.547)\end{array}$ & & $\begin{array}{l}-2.985 * * * \\
(0.570)\end{array}$ & & & \\
\hline Outsourcing & & & & & & & \\
\hline Narrow Measure & $\begin{array}{l}-2.572 * * * \\
(0.866)\end{array}$ & $\begin{array}{l}-2.384 * * * \\
(0.902)\end{array}$ & $\begin{array}{l}-2.541 * * * \\
(0.884)\end{array}$ & $\begin{array}{l}-2.336 * * * \\
(0.944)\end{array}$ & & & 24 \\
\hline $\begin{array}{l}\text { Share of Production Workers in } \\
\text { Total Value of Shipments }\end{array}$ & & $\begin{array}{l}-1.538 \\
(1.509)\end{array}$ & & $\begin{array}{l}-1.728 \\
(1.649)\end{array}$ & & & \\
\hline Broad Measure & $\begin{array}{l}-2.004 * \\
(1.129)\end{array}$ & $\begin{array}{l}-1.877^{*} \\
(1.133)\end{array}$ & $\begin{array}{l}-1.680 \\
(1.16)\end{array}$ & $\begin{array}{l}-1.883 \\
(1.179)\end{array}$ & & & 24 \\
\hline $\begin{array}{l}\text { Share of Production Workers in } \\
\text { Total Value of Shipments }\end{array}$ & & $\begin{array}{l}-3.065 * \\
(1.584)\end{array}$ & & $\begin{array}{l}-3.271^{*} \\
(1.791)\end{array}$ & & & \\
\hline Transportation Costs & $\begin{array}{l}3.861^{* * *} \\
(0.995)\end{array}$ & $\begin{array}{l}3.302 * * * \\
(0.913)\end{array}$ & $\begin{array}{l}3.721 * * * \\
(1.022)\end{array}$ & $\begin{array}{l}3.212 * * * \\
(0.909)\end{array}$ & $\begin{array}{l}3.803 \\
(2.425)\end{array}$ & $\begin{array}{l}2.570 \\
(0.295)\end{array}$ & 172 \\
\hline $\begin{array}{l}\text { Share of Production Workers in } \\
\text { Total Value of Shipments }\end{array}$ & & $\begin{array}{l}-2.494 * * * \\
(0.512)\end{array}$ & & $\begin{array}{l}-2.629 \\
(0.530)\end{array}$ & & & \\
\hline
\end{tabular}


Figure 1 Labor Demand Response to Increase in Wages

\subsection{Intermediate Input Production}

Domestic intermediate

input (D)

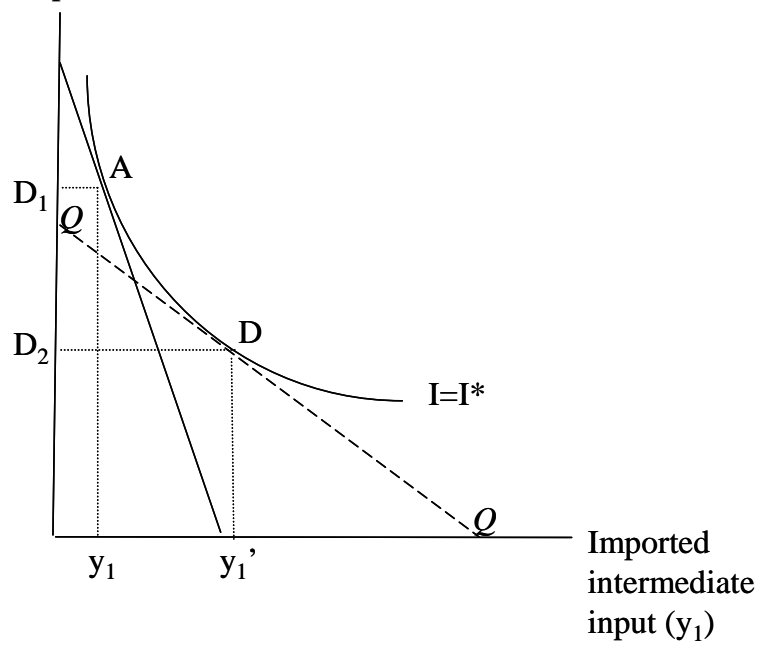

1.2 Domestic Intermediate Input Production

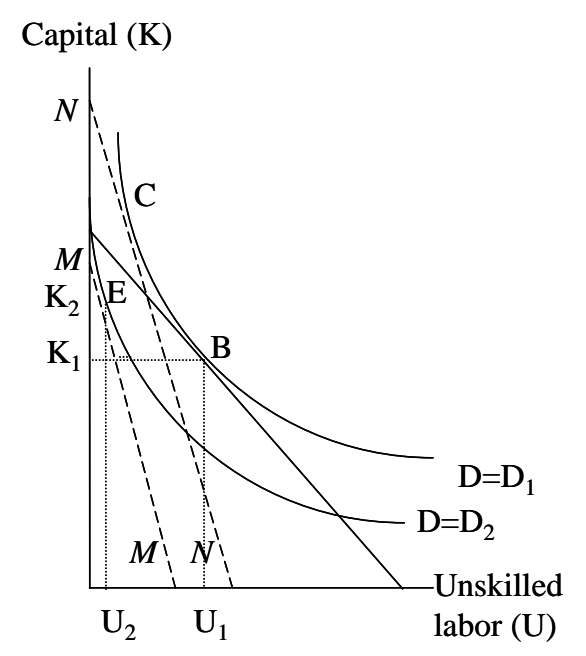

\section{Figure 2 Share of Unskilled Labor Cost in Total Value of Shipments}

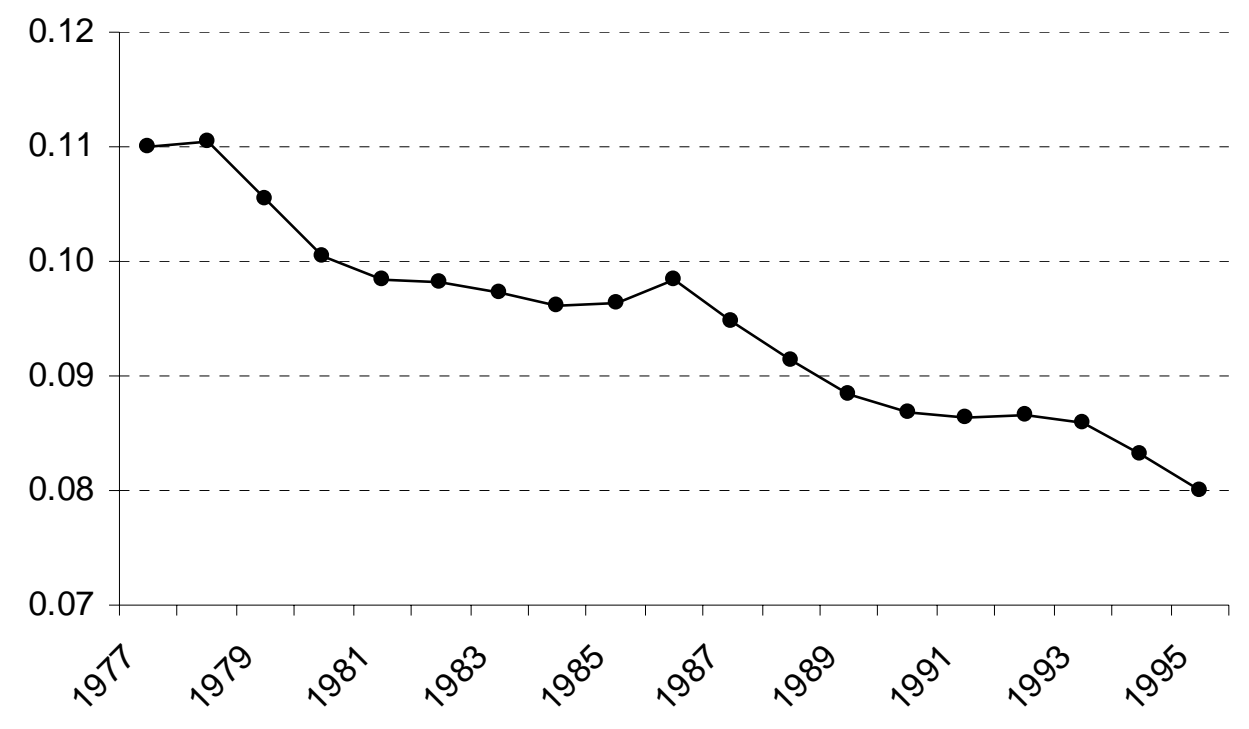

Calculated as a weighted average of (wage payments to unskilled workers)/(total value of shipments), for all manufacturing sector, for each year. 


\section{Figure 3 Manufacturing Sector: Balanced versus Unbalanced Panels}

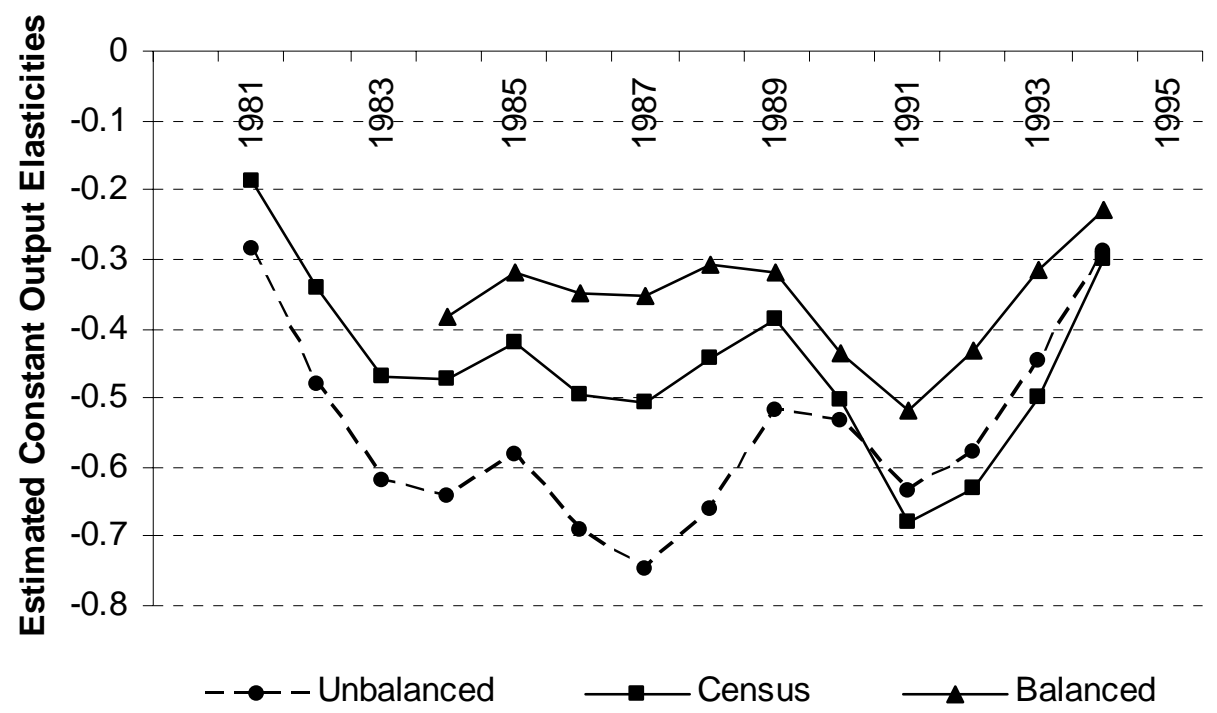

Labor demand elasticities for production workers estimated using state-level instrumental variable for all manufacturing. Equations are estimated in three year differences. The balanced sample includes plants that were surveyed each year during the 1977-1995 period. The Census sample includes plants that were surveyed in all the Census of Manufacturers between 1977 and 1995 (1977, 1982, 1987, and 1992). The unbalanced sample includes all the plants that were surveyed in a given year. 3-year moving averages are reported.

\section{Figure 4 Manufacturing Sector: IV estimates versus OLS}

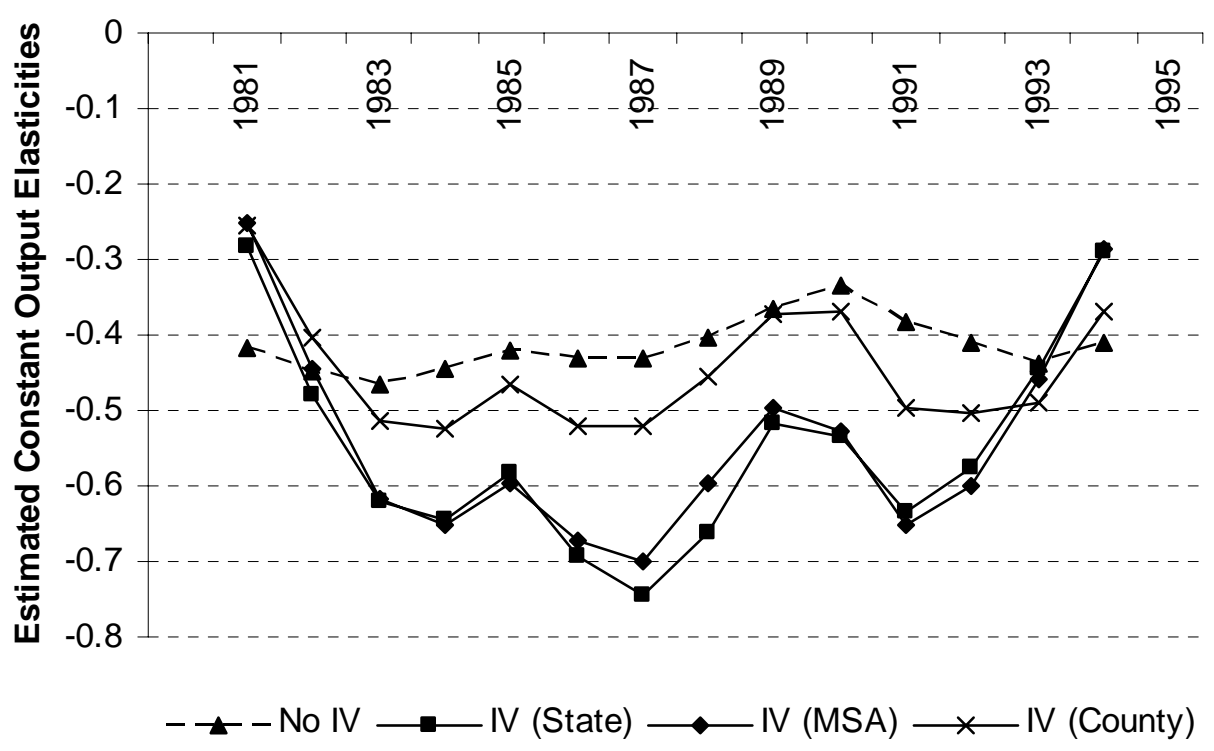

Labor demand elasticities for production workers estimated using state and county-level instrumental variables and OLS for all manufacturing, in three year differences. Three-year moving averages are reported. 


\section{Figure 5 Heavy Outsourcers and Other Industries}

\subsection{Unbalanced Sample}

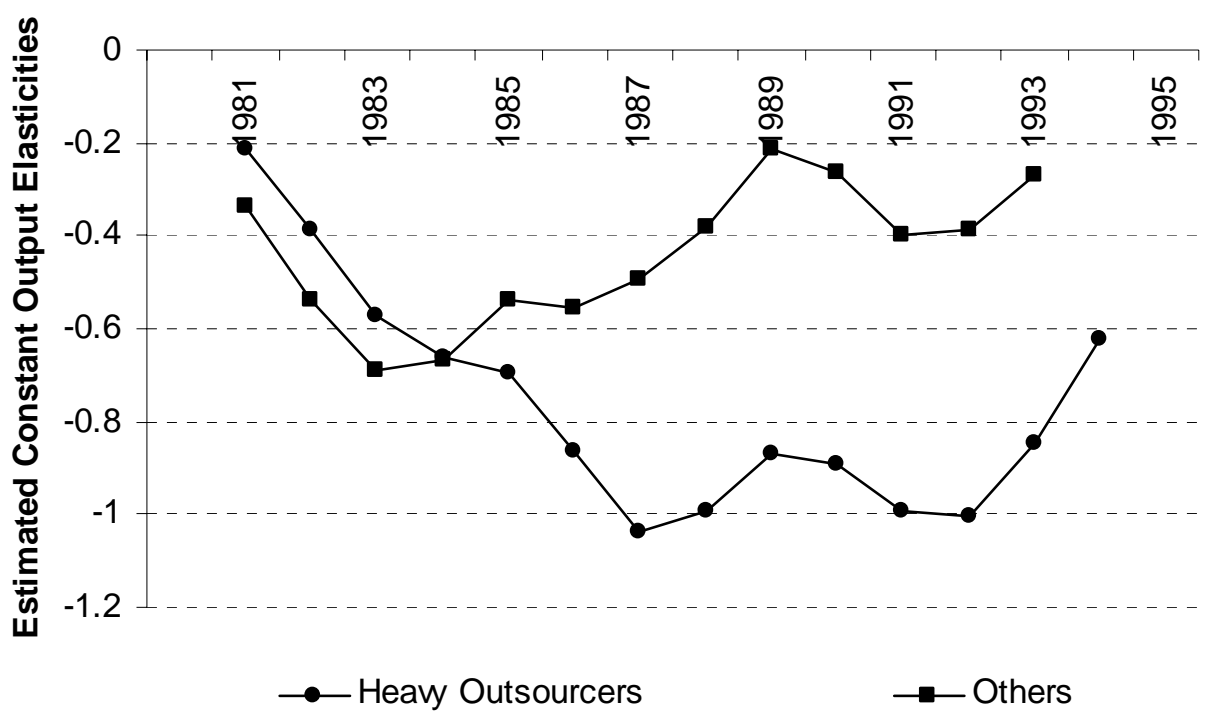

Labor demand elasticities for production workers estimated using state-level instrumental variable for industries that heavily outsource (SIC: 23, 31, 35, 36, 37, 38, and 39) and other industries. Equations are estimated in three year differences for the unbalanced sample that includes all the plants that were surveyed in a given year. 3-year moving averages are reported.

\subsection{Census Sample}

\section{2.a Moving Averages}

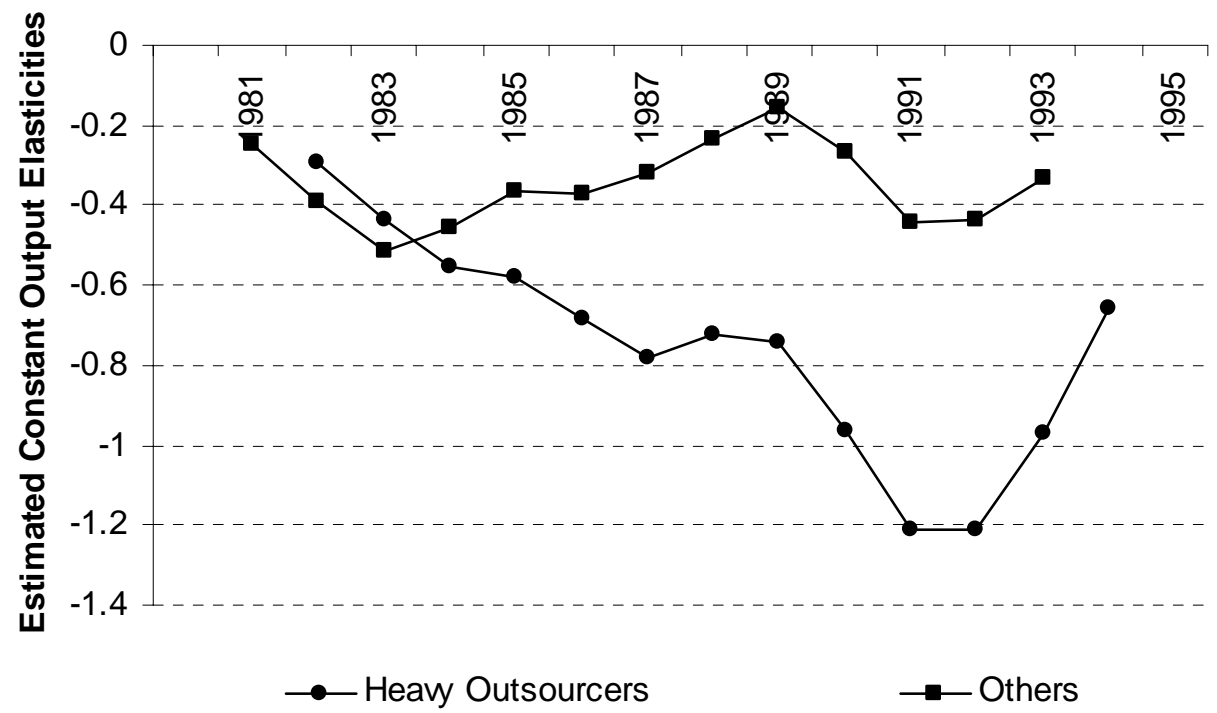

Labor demand elasticities for production workers estimated using state-level instrumental variable for industries that heavily outsource (SIC: 23, 31, 35, 36, 37, 38, and 39) and other industries. Equations are estimated in three year differences for the census sample that includes all the plants that were surveyed in all the Census of Manufacturers between 1977 and 1995 (1977, 1982, 1987, and 1992). Three-year moving averages are reported. 


\section{2.b Confidence Intervals}

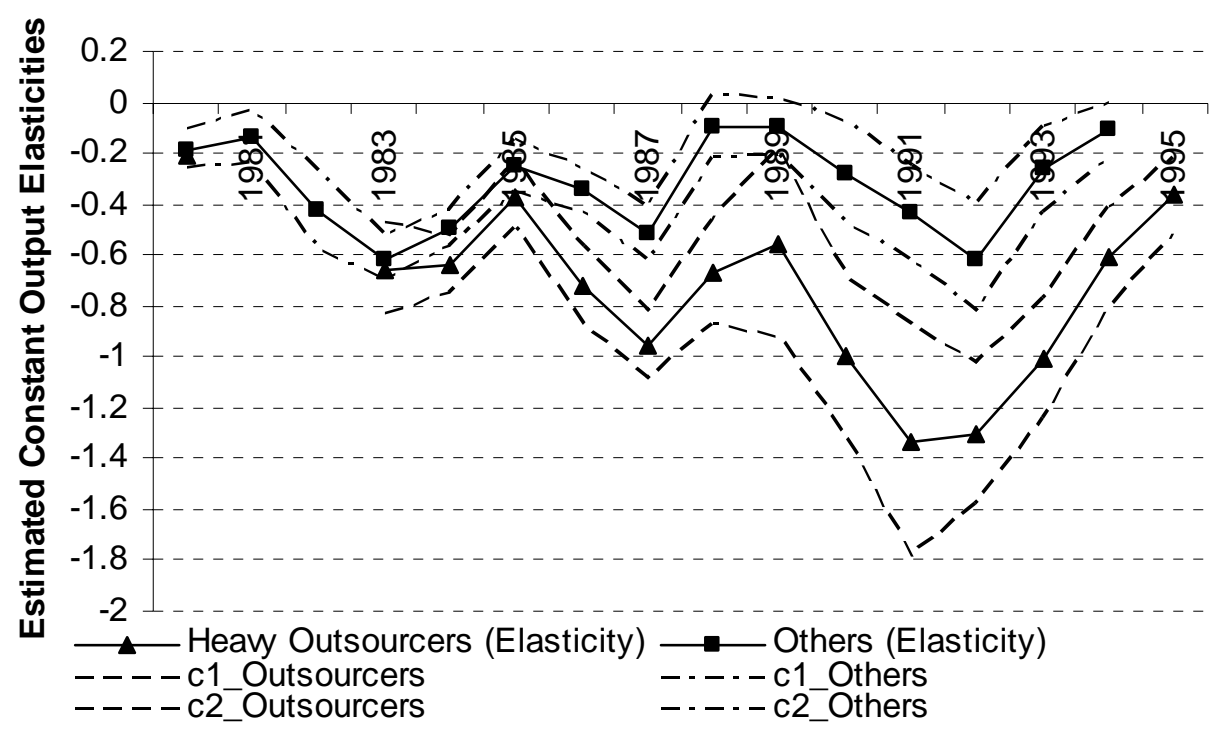

Labor demand elasticities for production workers estimated using state-level instrumental variable and the 95\% confidence intervals around the estimates, for industries that heavily outsource (SIC: 23, 31, 35, 36, 37, 38, and 39) and other industries. Equations are estimated in three year differences for the census sample that includes all the plants that were surveyed in all the Census of Manufacturers between 1977 and 1995 (1977, 1982, 1987, and 1992).

\section{2.c Three-year Differences versus Five-year Differences}

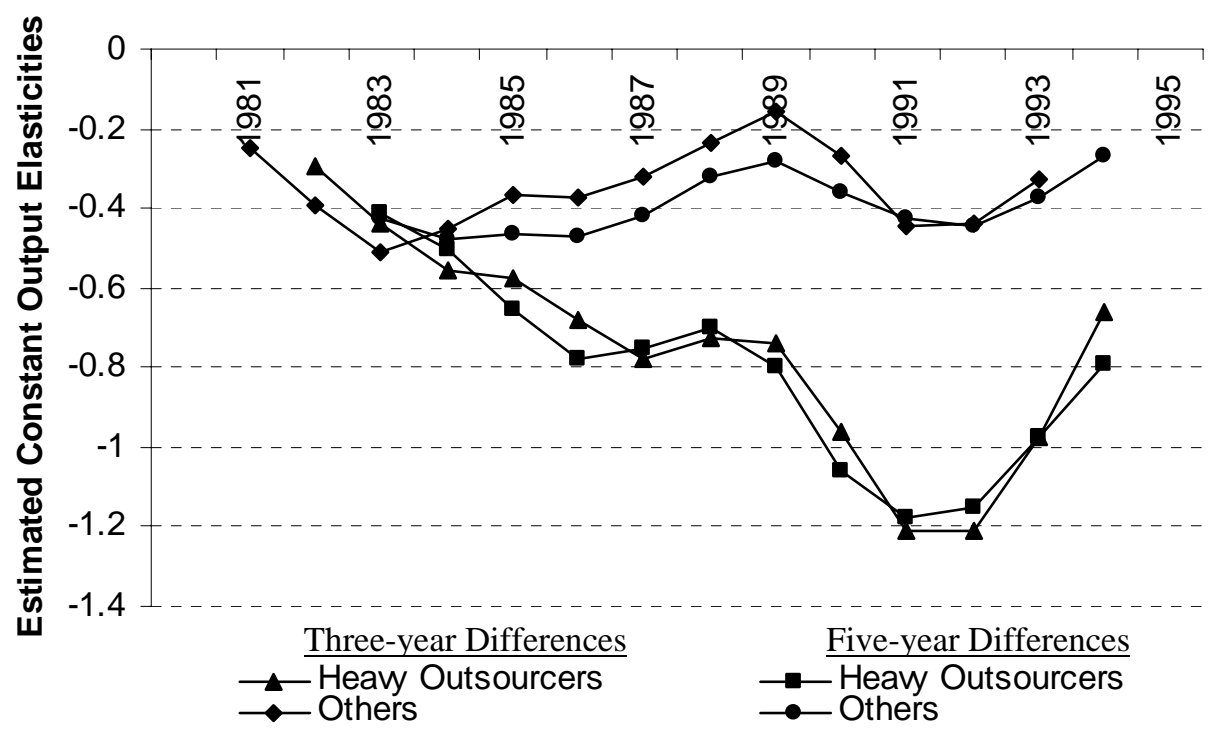

Labor demand elasticities for production workers estimated using state-level instrumental variable for industries that heavily outsource (SIC: 23, 31, 35, 36, 37, 38, and 39) and other industries. Equations are estimated in three-year differences and five-year differences for the census sample that includes all the plants that were surveyed in all the Census of Manufacturers between 1977 and 1995 (1977, 1982, 1987, and 1992). Three-year moving averages are reported. 


\section{2.d Alternative Instrumental Variables}

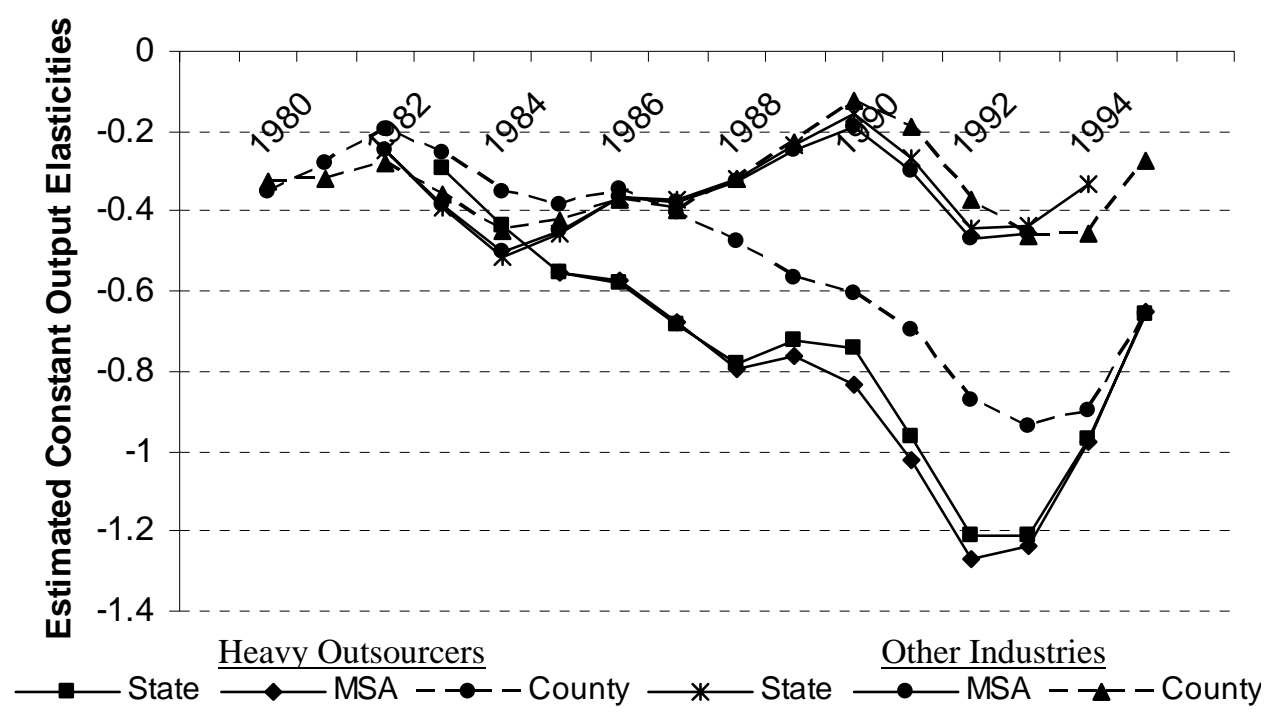

Labor demand elasticities for production workers estimated using state level, MSA level and county-level instrumental variables for industries that heavily outsource (SIC: 23, 31, 35, 36, 37, 38, and 39) and other industries. Equations are estimated in three year differences for the census sample that includes all the plants that were surveyed in all the Census of Manufacturers between 1977 and 1995 (1977, 1982, 1987, and 1992). Three-year moving averages are reported. 